(c) American Dairy Science Association, 2004.

\title{
Resynchronizing Estrus with Progesterone or Progesterone Plus Estrogen in Cows of Unknown Pregnancy Status*
}

\section{S. Z. El-Zarkouny† and J. S. Stevenson}

Department of Animal Sciences and Industry Kansas State University, Manhattan, KS 66506-0201 experiment 1 . Combining estrogen with $\mathrm{P} 4$ in experiment 2 had no detrimental effects on established pregnancies or subsequent conception and failed to improve return rates beyond $\mathrm{P} 4$ alone.

(Key words: estrogen, progesterone, resynchronization, fertility)

Abbreviation key: CIDR = controlled internal drugreleasing intravaginal insert containing $\mathrm{P} 4 ; \mathbf{C L}=$ corpus luteum; $\mathbf{E 2 - 1 7} \boldsymbol{\beta}$ = estradiol-17 $\beta$; $\mathbf{E B}=$ estradiol benzoate; ECP = estradiol cypionate; Ovsynch = injection of GnRH $7 \mathrm{~d}$ before and $48 \mathrm{~h}$ after an injection of $\mathrm{PGF}_{2 \alpha}$, with one TAI at 16 to $20 \mathrm{~h}$ after the second GnRH injection; Ovsynch + CIDR = Ovsynch plus a CIDR insert for $7 \mathrm{~d}$ at the time of first GnRH injection; $\mathbf{P 4}=$ progesterone; $\mathbf{T A I}=$ timed $\mathrm{AI}$.

\section{INTRODUCTION}

Because of conception failure and embryo loss, heifers return to estrus in a more scattered pattern after inseminations than noninseminated heifers (Van Cleeff et al., 1996). To prevent early returns to estrus of nonpregnant, previously estrus-synchronized cows or heifers, others have used an intravaginal progesterone (P4)releasing controlled internal drug release (CIDR) insert on d 16 after insemination for $5 \mathrm{~d}$ (McMillan and Macmillan, 1989), on d 17 for 5 d (Van Cleeff et al., 1996), or have inserted a P4-releasing intravaginal device on $\mathrm{d} 13$ for $7 \mathrm{~d}$ (Stevenson and Mee, 1991). Reuse of the CIDR insert did (Stevenson et al., 2003) or did not (McMillan and Macmillan, 1989) alter either overall return rates or conception rates to first service in beef cows and heifers, but did synchronize returns to estrus. Inserting a CIDR between d 13 and 20 after timed AI (TAI) might synchronize follicular development in nonpregnant cows (Kang et al., 1999) and might synchronize returns to estrus in a 3-d period without affecting conceptions resulting from the first $\mathrm{AI}$ (Xu et al., 1997).

Timed AI of dairy cows has changed the dairy industry by providing greater options for reproductive management of lactating dairy cows. Introduction of a successful TAI protocol known as Ovsynch (injection of 
GnRH $7 \mathrm{~d}$ before and $48 \mathrm{~h}$ after injection with $\mathrm{PGF}_{2 \alpha}$ with one TAI at 16 to $20 \mathrm{~h}$ after the second GnRH injection) (Pursley et al., 1995) provided the option for cluster breeding of cows at first service or of any group of nonpregnant cows while producing reasonable pregnancy rates (Burke et al., 1996). Potential for synchronized ovulation and TAI to improve reproductive traits can be extended by strategically manipulating the repeat estrus in dairy (Macmillan et al., 1999) or beef cows (Stevenson et al., 2003).

During proestrus, endogenous estrogen increases and induces a preovulatory surge of $\mathrm{LH}$ (Stumpf et al., 1991). Because of the positive feedback effect of estradiol-17 $\beta(\mathbf{E 2 - 1 7} \beta)$ on LH, estradiol benzoate (EB) has been used to synchronize ovulation (Dailey et al., 1986; Fike et al., 1997). A small dose of EB injected on d 12, 13, or 14 after AI synchronized returns to a 9- to 10-d period and increased fertility associated with the second AI, whereas pregnancy rates after the initial AI were unaffected (Macmillan et al., 1999). Reduced conception may occur after any progestin-based synchronization protocol and may be related, in part, to follicular and oocyte asynchrony, in which aged or persistent follicles ovulate oocytes of lesser fertility (Mihm et al., 1994; Ahmad et al., 1995). Persistent follicles may be avoided by using estrogen at the start of progestin treatment to induce atresia of dominant follicles, resulting in emergence of a new cohort of follicles 3 to $5 \mathrm{~d}$ later (Bo et al., 1995; Burke et al., 1999).

The objective of the first experiment was to determine the effects of a P4-based treatment on resynchronized returns to estrus, conception rate of the first eligible (synchronized) estrus, and fertility of cows impregnated before treatment (CIDR applied between d 13 and 20 after a previous TAI applied to lactating dairy cattle of unknown pregnancy status). A second experiment tested the hypothesis that addition of EB or estradiol cypionate (ECP) injections to CIDR after TAI, would increase the synchrony of returns to second service beyond that of using $\mathrm{P} 4$ alone because the dominant follicle would turnover in response to the first estrogen injection and estrus would be induced by the second estrogen injection. Therefore, objectives of experiment 2 were to determine whether these treatments altered established pregnancy rates and subsequent fertility of nonpregnant cows in which estrus was resynchronized (in part because of estrogen-induced follicle turnover) and reinsemination occurred at the first eligible estrus after TAI.

\section{MATERIALS AND METHODS}

\section{Experiment 1}

Herd management. Lactating Holstein cows from 2 different cooperating dairy herds in northeast Kansas were studied between November 1999 and June 2000. Herd sizes ranged from 400 to 600 cows, having annual rolling herd averages of 10,000 to $11,500 \mathrm{~kg}$ of milk. Cows were milked $3 \times$ daily and housed in covered 2 - or 4-row barns equipped with head locks along the feed line and free stalls bedded with sand. Cows were fed to meet or exceed NRC (1989) recommendations for lactating cows. Biweekly injections of recombinant bST were administered to all cows beginning in the ninth week of lactation. A TMR consisting of chopped alfalfa, corn silage, whole cottonseed, and a concentrate-mineral mix was offered twice daily. Cows had ad libitum access to fresh water.

Ovulation was previously synchronized with the Ovsynch protocol, which consisted of $2100-\mu \mathrm{g}$ injections of GnRH (Cystorelin; Merial, Iselin, NJ) 9 d apart with a 25-mg injection of $\mathrm{PGF}_{2 \alpha}$ (Lutalyse; Pharmacia Animal Health, Kalamazoo, MI) $48 \mathrm{~h}$ before the second injection of GnRH. One-half of these cows received a new CIDR for $7 \mathrm{~d}$, beginning at the time of the first $\mathrm{GnRH}$ injection in the Ovsynch protocol, and were inseminated (TAI) at 16 to $20 \mathrm{~h}$ after the second $\mathrm{GnRH}$ injection between 59 and 79 DIM (El-Zarkouny et al., 2004). At the outset of the previously applied treatments, cows were preassigned to 2 postbreeding treatments so that equal numbers of cows within lactation block (1 vs. $2+$ ) were balanced in each of the prebreeding treatments. Because of the a priori assignment of prebreeding and postbreeding (current experiment) treatments, residual effects of prebreeding treatments, if any, were equally balanced over the 2 postbreeding treatments of the current experiment. In none of the analyses performed was there any evidence for residual effects.

The 2 postbreeding treatments that constitute this experiment included a once-used CIDR (InterAg, Hamilton, NZ, which contained either 1.38 or $1.9 \mathrm{~g}$ of $\mathrm{P} 4$ when new) on d 13 after TAI for $7 \mathrm{~d}$ (removed on $\mathrm{d} 20$ ) to resynchronize returns to estrus (CIDR; $\mathrm{n}=300$ ) or no further treatment (control) after the initial TAI ( $\mathrm{n}=$ 330; Figure 1). Dose of P4-containing CIDR insert was balanced among lactation blocks of cows in previous prebreeding treatments. We have shown that once- or twice-used CIDR inserts release sufficient $\mathrm{P} 4$ during $7 \mathrm{~d}$ to prevent recurrence of estrus (Stevenson et al., 2003). Cows were monitored for estrus daily after the initial TAI by using both visual detection and reading of tail chalk. Cows that returned to estrus after insert removal were reinseminated when visually detected in estrus or when tail chalk was smudged (chalk rub) or missing as noted at each morning observation. Pregnancy status was determined by transrectal ultrasonography (real time, B-Mode, linear array, diagnostic, ultrasound scanner equipped with a $5-\mathrm{MHz}$ transducer; Aloka $500 \mathrm{~V}$, Wallingford, CT) on d 29 in all cows regardless 


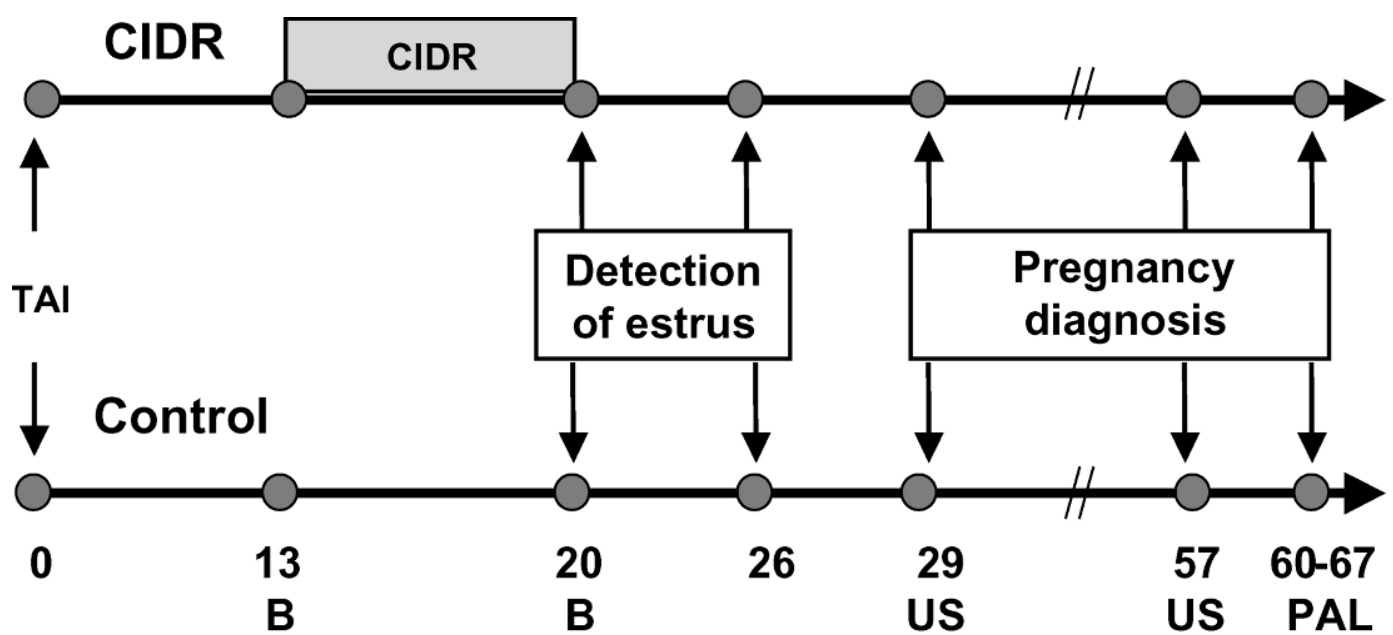

Days from TAl

Figure 1. Treatment protocol for resynchronization of estrus in lactating Holstein cows in experiment 1. Cows received a previously used controlled internal drug-releasing intravaginal insert containing progesterone (CIDR) for $7 \mathrm{~d}$ starting on d 13 after timed AI (TAI). Estrus was monitored daily after TAI, but synchronized estrus for this experiment was defined to that observed during the $6 \mathrm{~d}$ after CIDR removal. Blood (B) was collected on d 13 and 20. Pregnancy was diagnosed by transrectal ultrasonography (US) on d 29 and 57 after initial TAI. Cows reinseminated during the 20- to 26-d resynchronization period were diagnosed pregnant or not pregnant 40 to $46 \mathrm{~d}$ after AI (60 to $67 \mathrm{~d}$ after TAI) by transrectal palpation (PAL) of the uterus and its contents.

of whether reinsemination occurred. Pregnant cows on d 29 were reexamined on d 57 after TAI to determine embryo survival for those cows. Conception after the first eligible (resynchronized) estrus (those inseminated between d 20 and 26 after TAI) was determined 40 to $46 \mathrm{~d}$ later by uterine palpation per rectum.

For cows that became pregnant before treatment, embryo survival was calculated. If cows were identified pregnant on d 29 (successful occurrence of pregnancy recognition, development of extra embryonic membranes, and initial attachment; King et al., 1980, 1982), they were then reevaluated on $\mathrm{d} 57$ by ultrasonography. If the pregnancy persisted to $\mathrm{d} 57$ (successful formation of the fetus and transition from histotrophic to hemotrophic status), then survival was set as 1 ; if the pregnancy was lost, survival was set as 0 .

Blood collection. Blood samples were collected on d 13 (insertion of CIDR) and 20 (removal of CIDR) after TAI from all cows for later determination of $\mathrm{P} 4$ concentrations by radioimmunoassay (Skaggs et al., 1986). Inter- and intraassay CV were 6.9 and $6.4 \%$, respectively.

Statistical analyses. Pregnancy rates were measured on d 29 and 57 (resulting from pretreatment TAI); embryo survival between d 29 and 57 after TAI, conception rate to all second services, and conception rates after the first eligible (resynchronized as a result of treatment) estrus that occurred between d 20 and 26 after TAI were analyzed by ANOVA (by logistic regres- sion using procedure GENMOD for proportional data; SAS Inst., Inc., Cary, NC) with treatment (CIDR vs. control), lactation number ( 1 vs. $2+)$, herd $(\mathrm{n}=2)$, and all 2-way interactions with treatment, plus BCS and DIM at first service as covariables in the model. Analyses of percentages of pregnant and nonpregnant cows returning to estrus $<20 \mathrm{~d}, 20$ to $26 \mathrm{~d},>26 \mathrm{~d}$, or not at all, on the basis of ultrasonographic pregnancy diagnosis on d 29, was accomplished using procedure GENMOD as described previously, with a model that included treatment (CIDR vs. control), lactation number (1 vs. $2+$ ), their interaction, pregnancy status on d 29, plus BCS and DIM at first service as covariables in the model. Concentrations of P4 on d 20 after TAI based on the previously cited categories were analyzed with a similar model, but using procedure GLM in SAS. Means for treatment, herd, and lactation number were separated by resulting $F$-tests in the ANOVA.

\section{Experiment 2}

Lactating Holstein cows were previously inseminated in 20 breeding clusters initiated bi- or triweekly between November 1999 and December 2000 at the Kansas State University Dairy Teaching and Research Center. Cows in the first 5 breeding clusters $(n=63)$ were housed individually in tie stalls during part of the experiment. Otherwise, the remainder (15 clusters consisting of 133 cows) was housed in covered free stalls 


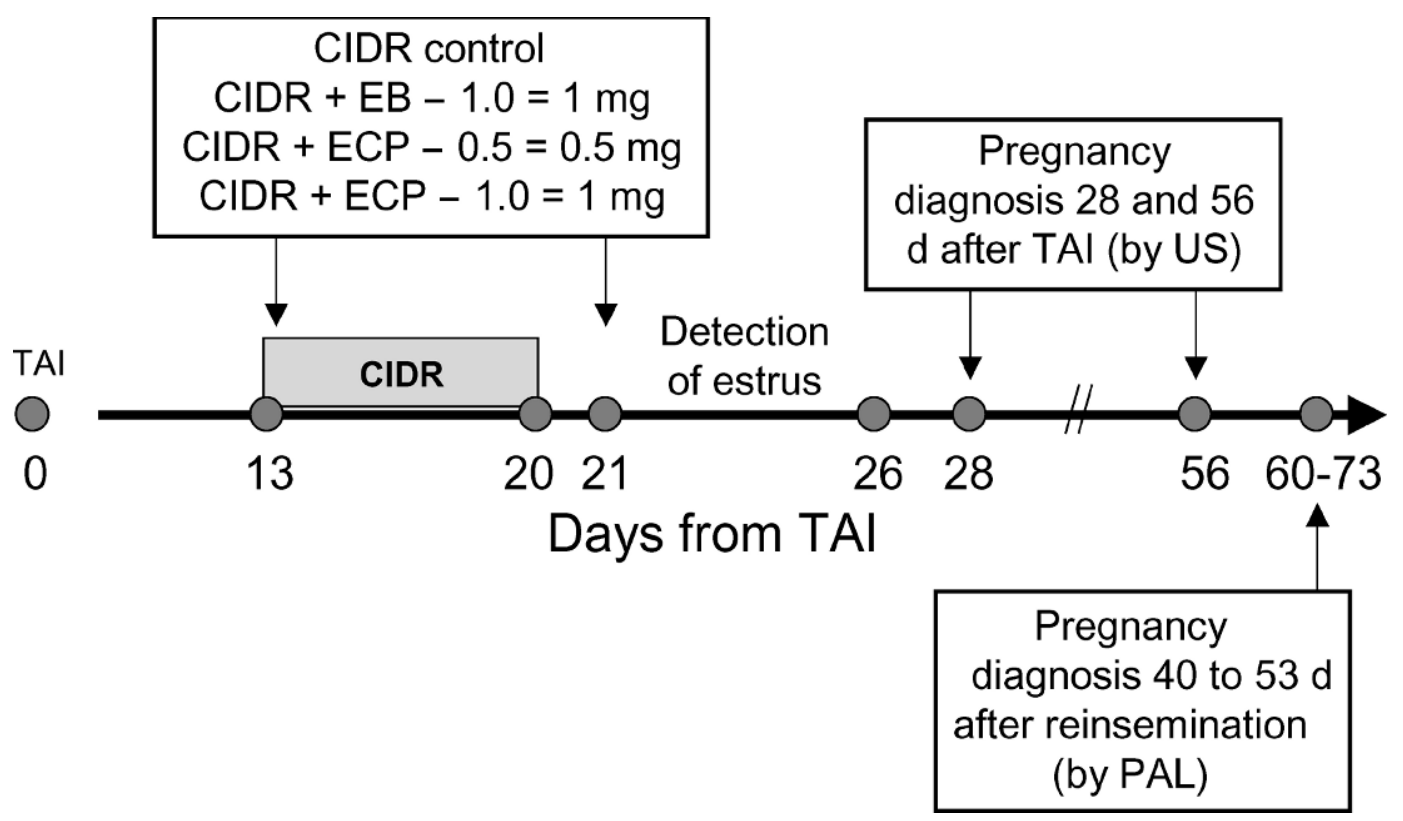

Figure 2. Treatment protocol for resynchronization of estrus in experiment 2. A controlled internal drug-releasing intravaginal insert containing progesterone (CIDR) was applied for $7 \mathrm{~d}$ on d 13 and removed on d 20 after initial timed AI (TAI). At insertion and $24 \mathrm{~h}$ after removal, cows received no treatment (control), $1 \mathrm{mg}$ of estradiol benzoate (EB), or $0.5 \mathrm{mg}$ or $1.0 \mathrm{mg}$ of estradiol cypionate (ECP). Blood was collected daily from d 13 to 24. Pregnancy was diagnosed by transrectal ultrasonography (US) on d 28 and 56 after the initial TAI. Cows reinseminated during the 20- to 26-d resynchronization period were diagnosed pregnant or not pregnant 40 to $53 \mathrm{~d}$ after AI (d 60 to 73 after TAI) by transrectal palpation (PAL) of the uterus and its contents.

bedded with sand. The herd consisted of approximately 200 cows with an annual rolling herd average of 10,400 $\mathrm{kg}$ of milk (milked $2 \times$ daily). Biweekly injections of recombinant bST were administered to all cows beginning in the ninth week of lactation. All cows were fed to meet or exceed NRC (1989) recommendations for lactating cows. A total mixed diet consisting of chopped alfalfa, corn silage, whole cottonseed, and a concentrate-mineral mix was offered twice daily. Cows had ad libitum access to fresh water.

Experimental design. Before TAI, ovulation was synchronized in 196 cows by using the Ovsynch protocol as described in experiment 1 . Inseminations (TAI) occurred at 16 to $20 \mathrm{~h}$ after the second GnRH injection. The first injection of $\mathrm{GnRH}$ was given at random stages of the estrous cycle, and a new CIDR containing 1.38 $\mathrm{g}$ of $\mathrm{P} 4$ was placed per vagina at the time of first $\mathrm{GnRH}$ injection and removed $7 \mathrm{~d}$ later at the time of the $\mathrm{PGF}_{2 \alpha}$ injection. Cows were fitted with an electronic estrusdetection device (HeatWatch; DDx, Inc., Denver, CO) for detection of characteristics associated with standing behavior.

After TAI, the once-used CIDR was reinserted in each cow of unknown pregnancy status on $\mathrm{d} 13$ for $7 \mathrm{~d}$ to prevent return to estrus and was removed on $\mathrm{d} 20$. Cows within each of 20 breeding clusters were blocked by lactation number ( 1 vs. $2+$ ) and assigned randomly to each of 4 treatments (Figure 2): 1) CIDR controls $(\mathrm{n}=50)$ received no further treatment; 2$) 1 \mathrm{mg}$ of EB (Sigma Chemical Co., St. Louis, MO; CIDR + EB - 1.0 [n = 47]) in sesame oil; 3) $0.5 \mathrm{mg}$ of ECP (Pharmacia Animal Health, Kalamazoo, MI; CIDR + ECP - 0.5 [n = 51]); or 4) $1 \mathrm{mg}$ of ECP (CIDR + ECP - 1.0 [n = 48]) on d 13 after TAI. Estrogen injections were repeated at the same dose in each cow $24 \mathrm{~h}$ after CIDR removal ( 21 after TAI). Two hypotheses were tested. First was whether the dominant follicle identified on d 13 would turn over in response to the first estrogen injection. Second was whether the second injection would further increase the proportion of cows detected in estrus compared with cows receiving only the used CIDR.

DMI and milk yield. The first 5 breeding clusters (63 cows) were moved as groups every 2 to $3 \mathrm{wk}$ to indoor tie stalls 8 to $9 \mathrm{~d}$ after TAI before treatments were applied to facilitate adaption to tie stalls. Cows were fed individually to produce $10 \%$ orts daily and were moved twice daily to the milking parlor for milking. Daily DMI and milk yield were measured during an 8-d period after the first estrogen injection; then, cows were relocated to free stalls $24 \mathrm{~h}$ before the second estrogen injection.

Estrual behavior. Activity was monitored electronically during treatments and for as long as $5 \mathrm{~d}$ after the last estrogen injection on d 21. Activity included duration of estrus and frequency and duration of indi- 
vidual and total standing time. Cows having at least 4 or more standing events of at least $2 \mathrm{~s}$ per standing event were defined to be in estrus; otherwise, those data were eliminated as false-positive events.

Pregnancy was confirmed in all cows on d 28 (regardless of whether reinsemination occurred) by transrectal ultrasonography as described for experiment 1 (Figure 2). Pregnancy was reconfirmed on d 56 after TAI to assess rates of embryo survival in cows that were diagnosed pregnant on $\mathrm{d} 28$. Cows returning to estrus were reinseminated according to the a.m.-p.m. rule. Conception rates at the first eligible (resynchronized) estrus (those inseminated on d 20 to 26 after TAI) were assessed by uterine palpation per rectum at 40 to $53 \mathrm{~d}$ after AI (Figure 2).

Ovarian ultrasonography. Ovarian structures were monitored daily by using transrectal ultrasonography from d 13 to 24 after TAI in the same 63 cows that were housed in a tie-stall barn. Any cow without a corpus luteum $(\mathbf{C L})$ on $\mathrm{d}$ 13, or without subsequently determined elevated concentrations of $\mathrm{P} 4$ typical of mid diestrus, was excluded. Location of the CL and size and location of the largest follicle were determined. All additional ovarian follicles were sized using electronic calipers (average of vertical and horizontal measures) and were mapped daily. Our interest was to determine day of emergence of the second and third dominant follicle (3-wave cows) and the proportion of cows with 3 follicular waves resulting from likely turnover of the second wave dominant follicle after estrogen injection. Emergence of the second wave was estimated by back tracking follicles to determine when they emerged as a 4- to 5-mm follicle. In some instances, this occurred before d 13 (first day of ovarian scans). When follicle size observed on d 13 exceeded $5 \mathrm{~mm}$, day of emergence was estimated by assuming that follicles increased in diameter by 1.5 to $2 \mathrm{~mm} / \mathrm{d}$. Change in the proportion of cows with 2 vs. 3 follicular waves that differed from that observed in the control was assumed to result from estrogen injections as part of various treatments.

Blood collection. Blood samples were collected via coccygeal venipuncture on d 13 to 24 after the initial TAI. Blood was stored at $5^{\circ} \mathrm{C}$ for $<24 \mathrm{~h}$ until serum was harvested by centrifugation. Serum samples were stored at $\sim 20^{\circ} \mathrm{C}$ until assayed by radioimmunoassay for P4 (Skaggs et al., 1986) and E2-17 $\beta$ (Perry et al., 1991). Inter- and intraassay coefficients of variation of $16 \mathrm{P} 4$ assays were 7.8 and $6.3 \%$, respectively. Those for $6 \mathrm{E} 2-$ $17 \beta$ assays were 15.4 and $12.3 \%$, respectively.

Embryo survival. For cows that became pregnant before treatment, embryo survival was calculated as described in experiment 1 . Pregnancy was diagnosed at 4 different stages: $\mathrm{d} 24$ by elevated concentrations of $\mathrm{P} 4$ on d 21 to 24 (evidence for recognition of preg- nancy); d 28 by ultrasonography; d 40 to 46 by palpation; and $d 56$ by ultrasonography. Survival of embryos from d 24 to 28 provides evidence for development of extra embryonic membranes and initial attachment; survival of embryos from d 28 to 40 to 46 provides evidence for development of some placentomes and early placentation; and survival of embryos from d 40 to 46 to 56 provides evidence for successful formation of the fetus and transition from histotrophic to hemotrophic status (King et al., 1980, 1982).

Statistical analyses. Daily DMI and milk yield were analyzed by ANOVA by using the mixed models procedure (PROC MIXED; SAS Inst., Inc.). Treatment, lactation number ( 1 vs. $2+$ ), and their interaction were included in the model to test the main plot (error $=$ cow within treatment $\times$ lactation group). The split-plot error included day $\times$ cow within treatment $\times$ lactation group. Concentrations of $\mathrm{P} 4$ and $\mathrm{E} 2-17 \beta$ in serum were analyzed in separate but similar models. Of particular interest were concentrations of both steroids corresponding to $0,24,48$, and $72 \mathrm{~h}$ after estrogen injections on d 13 and 21. Concentrations of P4 on d 13 to 16 were analyzed from 104 cows and on d 21 to 24 from 185 cows. Concentrations of E2-17 $\beta$ from 72 cows were analyzed for both time periods. Cows were first sorted by pregnancy status, because pregnancy was a significant source of variation in preliminary analyses. Days to emergence (after TAI or d 13 after TAI) of either a second or third dominant follicle was analyzed using a model that consisted of treatment, lactation number ( 1 vs. 2+), their interaction, pregnancy status on $\mathrm{d} 28$, and replicate.

Analysis of percentages of pregnant and nonpregnant cows returning to estrus $<20 \mathrm{~d}, 20$ to $26 \mathrm{~d},>26 \mathrm{~d}$, or not all, on the basis of ultrasonographic pregnancy diagnosis on $\mathrm{d} 28$, was done as described in experiment 1 . Pregnancy rates determined by concentrations of $\mathrm{P} 4$ on d 21 to 24 (inclusively), at d 28 by ultrasonography, at d 40 to 46 by palpation, at d 56 by ultrasonography; embryo survival from d 24 to 28 , d 28 to 40 to 46 , d 40 to 46 to 56 , and d 24 to 56 ; percentages of cows that returned to their first eligible estrus between d 20 and 26 after TAI; conception rates of cows determined by palpation for the resynchronized AI (for those reinseminated between d 20 and 26); and conception rates of all second services, regardless of when they occurred after TAI were analyzed by ANOVA (by logistic regression using procedure GENMOD; SAS Inst. Inc.). The model included treatment (all 4 treatments or control vs. combined estrogen treatments), lactation number (1 vs. $2+$ ), their interaction, season $(\mathrm{n}=2)$, and BCS and DIM as covariables. Means were separated by using a priori orthogonal contrasts: CIDR control vs. estrogens; CIDR 

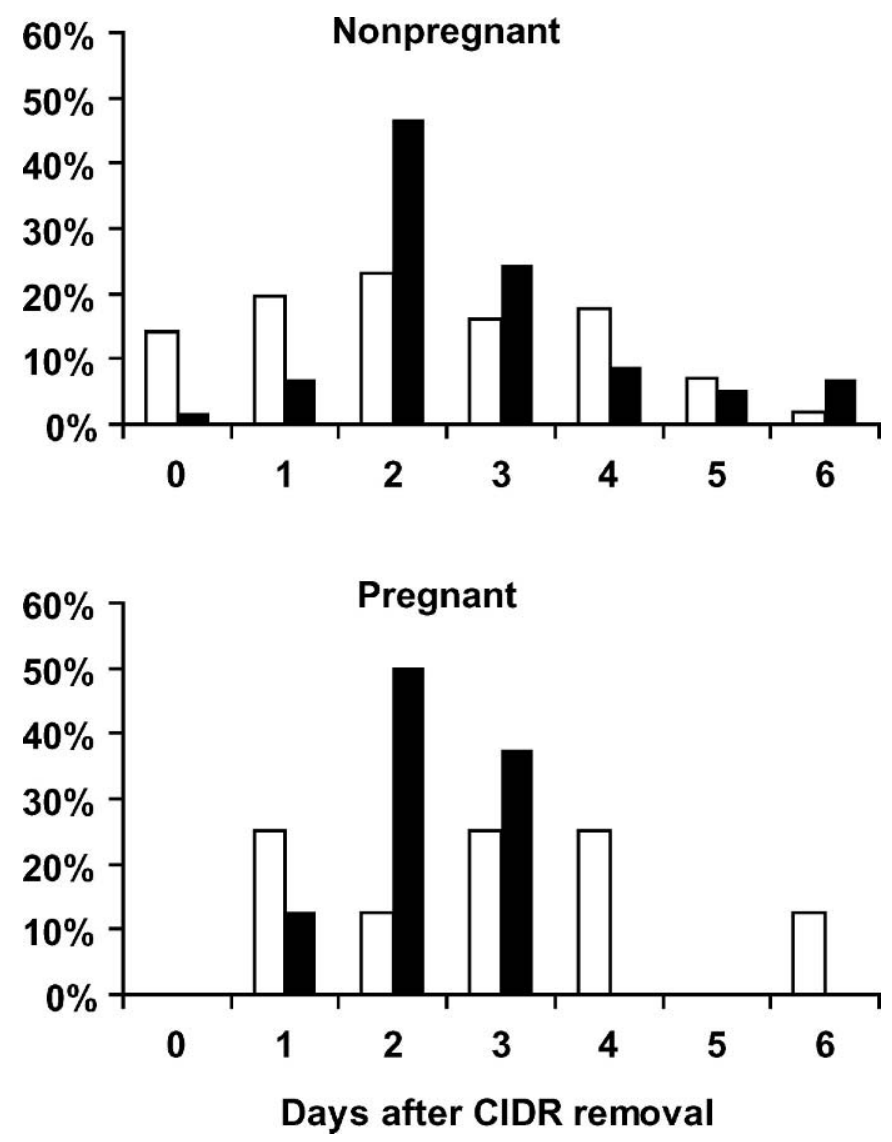

Figure 3. Pattern of return of lactating cows to first eligible estrus (d 20 to 26 after timed AI [TAI]) in experiment 1 after removal of a once-used controlled internal drug-releasing intravaginal insert containing progesterone (CIDR) (closed bars) or in controls (open bars) for nonpregnant (56 to 58 cows per treatment) and pregnant cows ( 8 cows per treatment) diagnosed on d 28 after the initial TAI or on d 8 after CIDR removal.

$+\mathrm{EB}$ vs. CIDR + ECP (both doses); and CIDR + ECP -0.5 vs. CIDR + ECP -1.0 .

\section{RESULTS}

\section{Experiment 1}

Patterns of return to first eligible estrus. Percentages of nonpregnant and pregnant cows returning to estrus by $6 \mathrm{~d}$ after CIDR insert removal are shown in Figure 3. Of 130 cows that returned to estrus and were reinseminated between 20 and $26 \mathrm{~d}$ after TAI, 16 cows (12.3\%; 8 per treatment) were later diagnosed pregnant on $\mathrm{d} 28$ after the TAI or $8 \mathrm{~d}$ after CIDR removal. Compared with controls, a consistent pattern of greater $(P$ $<0.05)$ synchrony occurred in both nonpregnant and pregnant cows on $\mathrm{d} 2$ and $\mathrm{d} 3$, respectively, after insert removal (no herd $\times$ treatment interaction). In contrast,
Table 1. Percentage returns to estrus after timed AI (TAI) as determined by visual detection and chalk rubs (experiment 1 ).

\begin{tabular}{lccc}
\hline & \multicolumn{3}{c}{ Treatment $^{1}$} \\
\cline { 2 - 4 } Item & Control & CIDR & Total \\
\hline & $-(\%$ [no.] returned nonpregnant cows $)-$ \\
Less than 20 d after TAI & $7.2(14)$ & $3.5(6)$ & $5.5^{* *}(20)$ \\
d 20 to 26 after TAI & $28.7(56)$ & $33.9(58)$ & $31.1^{* *}(114)$ \\
More than 26 d after TAI & $62.1(121)$ & $62.6(107)$ & $62.3^{* *}(228)$ \\
No return after TAI & $2.1(4)$ & $0.0(0)$ & $1.1^{* *}(4)$ \\
& $-(\%$ [no.] & returned pregnant cows $)$ \\
Less than 20 d after TAI & $0.7(1)$ & $0.0(0)$ & $0.4(1)$ \\
d 20 to 26 after TAI & $5.9(8)$ & $6.2(8)$ & $6.1(16)$ \\
More than 26 d after TAI & $40.7(55)$ & $30.2(39)$ & $35.6^{2}(94)$ \\
No return after TAI & $52.6(71)$ & $63.6(82)$ & $58.0(153)$ \\
\hline
\end{tabular}

${ }^{1}$ Cows were treated with a once-used controlled internal drug-releasing intravaginal insert containing progesterone (CIDR) for $7 \mathrm{~d}$ between d 13 and 20 after a TAI. Controls received no treatment.

${ }^{2}$ Includes cows that lost embryos and returned to estrus after the pregnancy diagnosis on $\mathrm{d} 28$.

**Different $(P<0.01)$ from pregnant cows within return category.

the pattern of return for controls was distributed somewhat evenly over the 7-d period.

Proportions of cows that returned to estrus after TAI (before d 20, d 20 to 26, after d 26, or not at all) were summarized by treatment and pregnancy status (Table 1). No treatment effects were detected, but as expected, pregnancy status on d 29 influenced the percentage of returns in each return category. More $(P<0.01)$ nonpregnant cows $(5.5 \%)$ expressed estrus during the treatment period compared with pregnant cows $(0.4 \%)$. During the target week of reinsemination (d 20 to 26), more $(P<0.01)$ nonpregnant cows $(31.1 \%)$ than pregnant cows $(6.1 \%)$ were detected in estrus. More than $62 \%$ of the nonpregnant cows returned to estrus after $\mathrm{d} 26$, which was greater $(P<0.01)$ than that of pregnant cows $(35.6 \%)$. The percentage of pregnant cows returning after d 26 included those whose embryos did not survive to term. Nearly $60 \%$ of the pregnant cows did not return to estrus after TAI compared with only $1.1 \%$ of nonpregnant cows.

Average concentrations of $\mathrm{P} 4$ in cows on $\mathrm{d} 13$ were not different before assignment of cows to treatment. Among nonpregnant and pregnant cows (Figure 4), concentrations of $\mathrm{P} 4$ on d 20 were greater $(P<0.01)$ in pregnant cows, but were not different between treatments, regardless of when or whether they returned to estrus for reinsemination.

The $\mathrm{P} 4$ treatment failed to increase the overall return rates of all nonpregnant cows to the first eligible estrus (30.8\%) during d 20 to 26 after TAI compared with return rates of controls (27\%; Table 2). However, the percentage of nonpregnant cows that returned to estrus tended $(P=0.06)$ to differ between herds: $34.7 \%(\mathrm{n}=$ 

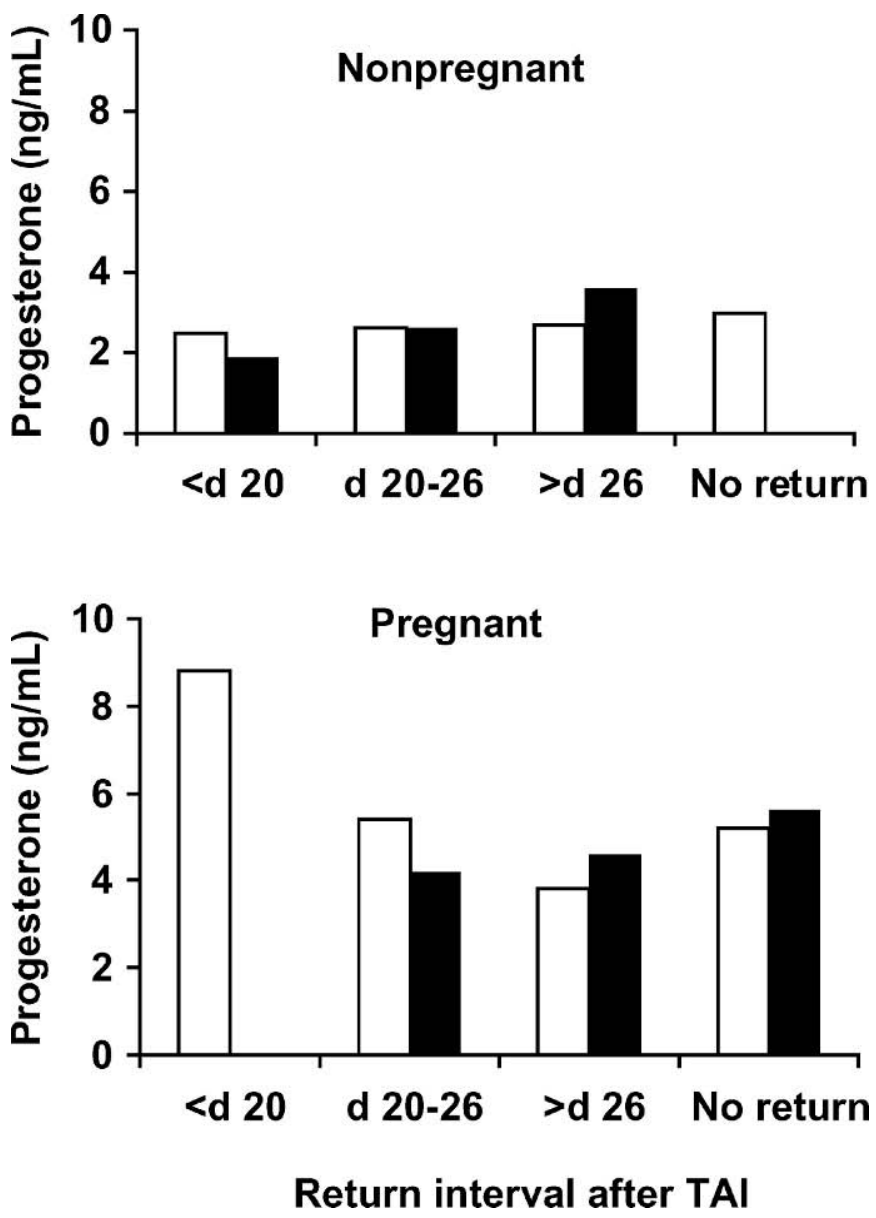

Figure 4. Concentrations of progesterone in the blood serum of nonpregnant and pregnant cows on $\mathrm{d} 20$ when a once-used controlled internal drug-releasing intravaginal insert containing progesterone (CIDR) was removed (closed bars; Experiment 1). Controls (open bars) received no treatment. Cows were classified according to the number of days after timed insemination (TAI) that they returned to estrus. Numbers of cows per category can be derived from Table 1 .

184) in the first herd and $23.1 \%(\mathrm{n}=174)$ in the second herd.

Fertility. Conception rate at the first eligible (resynchronized) estrus was just $63 \%$ of the rate in controls (20.0\% vs. $31.6 \%$; Table 2 ), but did not differ significantly with only 56 to 58 observations per treatment. Overall conception rates to the resynchronized estrus were greater $(P<0.05)$ in the first herd $(36.7 \%$; $\mathrm{n}=$ $44)$ than in the second herd $(14.9 \% ; \mathrm{n}=70)$. Although fertility after second service was nearly 2.5 times greater in the greater-fertility herd than the poorerfertility herd, resynchronized conception rate for cows treated with $\mathrm{P} 4$ in the poorer-fertility herd was similar to that for controls in the same herd ( $14.1 \%$ vs. $15.7 \%$, respectively). In contrast, in the greater-fertility herd, conception of P4-treated cows was $25.9 \%$, much less than that of controls $(47.5 \%)$.
Table 2. Percentage returns to second services, resynchronized conception rates, pregnancy rates resulting from first service (timed AI [TAI]), and embryo survival between d 29 and 57 after TAI (experiment 1).

\begin{tabular}{lll}
\hline & \multicolumn{2}{c}{ Treatment $^{1}$} \\
\cline { 2 - 3 } Item & Control & CIDR \\
\cline { 2 - 3 } & \multicolumn{2}{c}{$(\%$ [no.]) } \\
Return rates to second services $^{2}$ & $27.0(189)$ & $30.8(169)$ \\
Resynchronized conception rates $^{2}$ & $31.6(56)$ & $20.0(58)$ \\
Conception rates of all second services & $19.5(253)$ & $18.2(215)$ \\
Pregnancy rates on d 29 after TAI & $38.2(327)$ & $42.1(297)$ \\
Embryo survival between d 29 and 57 & $44.3(134)$ & $65.5^{* *(128)}$ \\
\hline
\end{tabular}

${ }^{1}$ Cows were treated with a once-used controlled internal drug-releasing intravaginal insert containing progesterone (CIDR) for $7 \mathrm{~d}$ between d 13 and 20 after a TAI. Controls received no treatment. Values are least squares percentages.

${ }^{2}$ Percentage of cows that returned to estrus between 20 and $26 \mathrm{~d}$ after TAI ( 0 and $6 \mathrm{~d}$ after CIDR removal) and their resulting conception rates. All of these are cows were diagnosed not pregnant $29 \mathrm{~d}$ after TAI.

${ }^{3}$ Unadjusted percentages were $51.9 \%$ for controls and $62.8 \%$ for CIDR.

**Different $(P<0.01)$ from control.

The CIDR imposed no detriment to established pregnancies resulting from TAI, inasmuch as resulting pregnancy rates differed from those of controls by just 3.9 percentage points (Table 2).

Further, proportionally more $(P<0.01)$ cows treated with $\mathrm{P} 4$ via the CIDR, diagnosed pregnant on $\mathrm{d} 29$, were still pregnant on d 57 after TAI compared with controls (Table 2). Embryo survival also was greater $(P=0.05)$ in first lactation cows than in older cows $(60.7 \%$ vs. $49 \%)$.

\section{Experiment 2}

Concentrations of E2-17 $\beta$ during treatment. Concentrations of E2-17 $\beta$ in serum were greater $(P<$ 0.001 ) in nonpregnant than in pregnant cows (Figure 5). Significant $(P<0.001)$ treatment $\times$ day interactions were detected within pregnancy status for the entire period from 13 to $24 \mathrm{~d}$. Serum E2-17 $\beta$ increased approximately 5 -fold in nonpregnant cows within $24 \mathrm{~h}$ of EB -1.0 injection compared with a 3 -fold increase in serum E2-17 $\beta$ in pregnant cows that were treated with EB 1.0. Among nonpregnant cows injected on $d 13$, concentrations of E2-17 $\beta$ were greater than those of controls from 24 to $72 \mathrm{~h}$ after EB -1.0 or ECP - 1.0 (differing $P$ values in Table 3 ). In contrast, the smaller dose of ECP did not increase concentrations of E2-17 $\beta$ in blood serum. Among pregnant cows after d 13 injections, only EB -1.0 or ECP - 1.0 increased E2-17 $\beta$ at $24 \mathrm{~h}$ (differing $P$ values). Only EB -1.0 tended $(P<0.10)$ to produce greater concentrations of E2-17 $\beta$ at $48 \mathrm{~h}$ after injection (Table 3). 

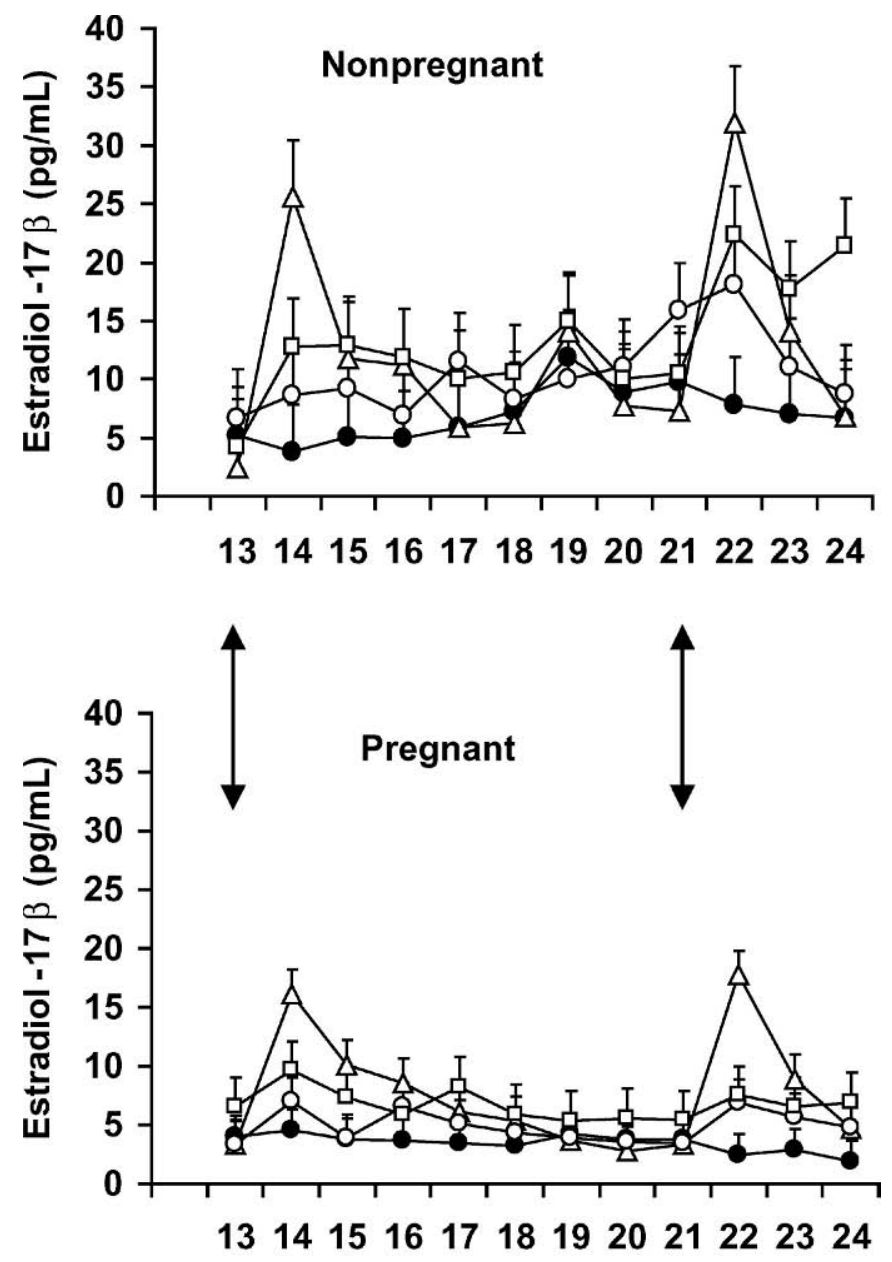

Days after TAI

Figure 5. Concentrations of estradiol- $17 \beta$ in the blood serum of nonpregnant and pregnant cows on d 13 to 24 after timed AI (TAI) in Experiment 2. Cows were previously treated with a once-used controlled internal drug-releasing intravaginal insert containing progesterone (CIDR) between d 13 and 20 (control; closed circles) after TAI or with the CIDR plus injections of $1 \mathrm{mg}$ of estradiol benzoate (EB; open triangles) or 0.5 (open circles) or 1.0 (open squares) $\mathrm{mg}$ of estradiol cypionate (ECP) on d 13 and 21. Number of nonpregnant cows illustrated ranged from 8 to 10 per treatment. Number of pregnant cows illustrated ranged from 7 to 11 per treatment. Arrows indicate estrogen injections.

Quite similar response patterns were observed after estrogen injections on $\mathrm{d} 21$ ( $24 \mathrm{~h}$ after CIDR removal). Compared with controls, injection of EB -1.0 increased $(P<0.05) \mathrm{E} 2-17 \beta$ at 24 and $48 \mathrm{~h}$ (pregnant cows only) in both nonpregnant and pregnant cows (Table 3), whereas either dose of ECP increased (differing $P$ values) $\mathrm{E} 2-17 \beta$ at $24 \mathrm{~h}$ among nonpregnant cows. The larger dose of ECP increased $(P<0.05) \mathrm{E} 2-17 \beta$ at 24 and $72 \mathrm{~h}$ among nonpregnant and pregnant cows compared with controls.
Concentrations of P4 during treatment. Mean concentrations and patterns of $\mathrm{P} 4$ in serum were different $(P<0.01)$ in pregnant vs. nonpregnant cows during the 13- to 24-d period after TAI (Figure 6). On and after d 16, concentrations of $\mathrm{P} 4$ were consistently lower in nonpregnant cows treated with estrogen. Compared with nonpregnant controls after d 13 estrogen injections, ECP-treated nonpregnant cows on d 13 and 14 (ECP -0.5 cows only) had greater concentrations of $\mathrm{P} 4$ (differing $P$ values in Table 4). By 48 to $72 \mathrm{~h}$, serum $\mathrm{P} 4$ was reduced $(P<0.05)$ in nonpregnant cows previously treated with EB - 1.0 and ECP. Among pregnant cows, EB -1.0 reduced $(P<0.05)$ serum $\mathrm{P} 4$ compared with controls at 24 and $48 \mathrm{~h}$ after injection and tended $(P<$ $0.10)$ to do so in ECP - 1.0 cows at $48 \mathrm{~h}$.

Detrimental effects of estrogen on luteal function persisted until the second injections of those treated with EB - 1.0 or ECP - 1.0 and continued after the second injection of estrogen with concentrations of $\mathrm{P} 4$ that were lower $(P<0.05)$ than nonpregnant controls; reduced concentrations were evident for as long as $48 \mathrm{~h}$ with ECP -1.0 and at $48 \mathrm{~h}$ with ECP - 0.5 (Table 4). Among pregnant cows, EB - 1.0-treated cows had less $(P<$ 0.05 ) serum $\mathrm{P} 4$ on $\mathrm{d} 21$ and for as long as $72 \mathrm{~h}$ later.

Follicular characteristics. Effects of estrogen type and dose on emergence of the second and third follicular waves and proportions of cows in which a third dominant follicle subsequently emerged are summarized in Table 5. As expected, emergence of the second dominant follicle occurred earlier $(P<0.001)$ for cows having 3 follicular waves than for cows having 2 follicular waves (d $12.6 \pm 1[n=19]$ vs. $d 15.1 \pm 0.8[n=40]$ ). Proportions of cows having 3 follicular waves did not differ among treatments, although $18.8 \%$ (3 of 16) of controls and $36.4 \%$ (16 of 43) of estrogen-treated cows had 3 follicular waves (Table 5). Compared with controls, among cows having 3 follicular waves, a third dominant follicle emerged earlier $(P<0.05)$ in estrogen-treated cows, measured as days since TAI or days after estrogen injections on d 13 (Table 5). No differences were detected in emergence of a new follicular waves among estrogens or doses of ECP, with mean days to new emergence ranging from 4.1 to $5.0 \pm 0.6 \mathrm{~d}$.

DMI and milk yield. Average daily DMI between estrogen injections on $d 13$ and 21 after TAI (16 cows per treatment except for CIDR + ECP $-0.5 ; \mathrm{n}=15$ ) ranged from 35 to $38 \pm 1.2 \mathrm{~kg}$ and were not negatively affected by estrogen. Daily milk yields (12 cows per treatment except for CIDR + ECP - 0.5; $\mathrm{n}=11$ ) ranged from 36 to $38 \pm 2 \mathrm{~kg}$ and also did not differ among treatments.

Patterns of return to first eligible estrus. Proportions of cows that returned prematurely to estrus while the CIDR was in situ were not different among treat- 
Table 3. Concentrations of estradiol $-17 \beta(\mathrm{pg} / \mathrm{mL})$ in the blood serum of cows at $0,24,48$, and $72 \mathrm{~h}$ after injections of estrogen on d 13 and 21 after timed AI (TAI; experiment 2).

\begin{tabular}{|c|c|c|c|c|c|c|c|c|c|c|c|c|}
\hline \multirow[b]{3}{*}{ Treatment $^{1}$} & \multicolumn{6}{|c|}{ Nonpregnant } & \multicolumn{6}{|c|}{ Pregnant } \\
\hline & \multirow[b]{2}{*}{ no. } & \multicolumn{4}{|c|}{ Hours after treatment } & \multirow[b]{2}{*}{$\pm \mathrm{SE}$} & \multirow[b]{2}{*}{ no. } & \multicolumn{4}{|c|}{ Hours after treatment } & \multirow[b]{2}{*}{$\pm \mathrm{SE}$} \\
\hline & & 0 & 24 & 48 & 72 & & & 0 & 24 & 48 & 72 & \\
\hline & & & & & 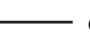 & $13 \mathrm{aft}$ & - TAI & & & & & \\
\hline Control & 8 & 5.7 & 4.3 & 5.6 & 5.3 & 2.9 & 11 & 4.0 & 4.5 & 3.8 & 3.7 & 2.2 \\
\hline EB -1.0 & 8 & 3.4 & $26.6^{\text {** }}$ & $12.8 \dagger$ & $12.2 \dagger$ & 3.4 & 9 & 3.4 & $16.1^{* *}$ & $10.1 \dagger$ & 8.6 & 2.4 \\
\hline ECP -0.5 & 10 & 7.4 & 9.3 & 9.9 & 7.6 & 2.9 & 10 & 3.3 & 7.0 & 3.9 & 6.6 & 2.8 \\
\hline ECP -1.0 & 9 & 5.1 & $13.7^{*}$ & $13.8^{*}$ & $12.7 \dagger$ & 2.9 & 7 & 6.5 & $9.6 \dagger$ & 7.4 & 5.9 & 2.2 \\
\hline Control & 8 & 9.3 & 7.3 & 6.6 & 6.2 & 4.9 & 11 & 3.8 & 2.4 & 2.8 & 1.8 & 1.8 \\
\hline $\mathrm{EB}-1.0$ & 8 & 6.4 & $31.1^{* *}$ & 13.2 & 6.0 & 5.7 & 9 & 3.4 & $17.8^{* *}$ & $8.9^{*}$ & 4.7 & 2.1 \\
\hline ECP - 0.5 & 9 & 15.3 & $17.6^{\dagger}$ & 10.6 & 8.3 & 5.3 & 10 & 3.2 & 6.6 & 5.4 & 4.5 & 2.5 \\
\hline ECP -1.0 & 9 & 10.0 & $21.7^{*}$ & 16.9 & $20.7^{*}$ & 5.8 & 7 & 5.5 & $7.6^{*}$ & 6.6 & $7.0^{*}$ & 1.9 \\
\hline
\end{tabular}

\footnotetext{
${ }^{1}$ All cows were treated with a once-used controlled internal drug releasing intravaginal insert containing (CIDR) for $7 \mathrm{~d}$ between d 13 and 20 after a TAI. Controls received no further treatment, whereas the remaining cows were injected with either $1 \mathrm{mg}$ of estradiol benzoate (EB - 1.0), $0.5 \mathrm{mg}$ of estradiol cypionate (ECP - 0.5), or $1.0 \mathrm{mg}$ of estradiol cypionate (ECP - 1.0) on d 13 and 21 ( $24 \mathrm{~h}$ after CIDR removal).

$\dagger$ Tended $(P<0.10)$ to differ from control within pregnancy status and hour after treatment on $\mathrm{d} 13$ or 21

*Different $(P<0.05)$ from control within pregnancy status and hour after treatment on d 13 or 21 .

**Different $(P<0.01)$ from control within pregnancy status and hour after treatment on d 13 or 21 .
}

ments (Table 6). No pregnant cows (on the basis of the d 28 diagnosis) returned to estrus before $\mathrm{d} 20$ after TAI, compared with $1.6 \%$ of nonpregnant cows treated with CIDR or CIDR + estrogen. Nearly $58 \%$ of the nonpregnant cows expressed estrus during the $6 \mathrm{~d}$ after CIDR removal, whereas no pregnant cows were detected. More than $40 \%$ of the nonpregnant cows returned to estrus after $\mathrm{d} 26$, which tended $(P=0.07)$ to differ from the percentage of pregnant cows $(27.8 \%)$ that returned after $d 26$. Pregnant cows that returned to estrus after d 26 were those whose embryos did not survive to term.

Characteristics of returned estrus. Average intervals to estrus (time to estrus after estrogen injection on $\mathrm{d} 21$ ) for those cows detected in estrus between $\mathrm{d} 20$ and 26 occurred 14 to $24 \mathrm{~h}$ earlier $(P<0.01)$ in cows treated with estrogen (Table 7). Duration of estrus, frequency of standing events per estrus, and duration of total standing events did not differ among treatments. The only evidence for a supraphysiologic effect of estrogen on any characteristic of estrus was the greater $(P$ $<0.05)$ duration of individual standing events in the CIDR + EB - 1.0 cows than in cows after either dose of ECP (Table 7).

Fertility. Pregnancy rates after TAI, calculated from the percentage of cows with serum $\mathrm{P} 4$ concentrations that equaled or exceeded $1 \mathrm{ng} / \mathrm{mL}$ on d 21 through 24 , at $\mathrm{d} 28$ by ultrasonography, at $\mathrm{d} 40$ to 46 by palpation, and at $\mathrm{d} 56$ by ultrasonography, were not different among treatments (Table 8). Adding the estrogen injections to the CIDR treatment imposed no detrimental effects on established pregnancies assessed by ultraso- nography either on d 28 or 56 after TAI (comparison of CIDR control with CIDR + estrogen; Table 8).

To determine whether resynchronization treatments had any ill effects on embryos that formed subsequent to conceptions at the TAI, rates of embryo survival between d 24 and 28 (evidence for development of extra embryonic membranes and initial attachment), d 28 and 40 to 46 (evidence for development of some placentomes and early placentation), d 40 to 46 and 56 (evidence for successful formation of the fetus and transition from histotrophic to hemotrophic status), and overall from d 24 to 56 (evidence for successful establishment of pregnancy to the fetal stage) are illustrated in Table 8. More embryos tended $(P=0.10)$ to survive in CIDR + estrogen-treated cows $(88.1 \%)$ than in controls (75.3\%) for d 24 to 28 after TAI; however, this trend did not carry over to later periods of embryo development (Table 8). In all treatments, most pregnancy loss occurred before rather than after d 40 to 46 .

Percentages of cows that returned to their first eligible estrus between 20 and $26 \mathrm{~d}$ after TAI were numerically greater $(P=0.13)$ for all estrogen treatments (Table 8). Resynchronized conception rates for cows inseminated during the period from d 20 to 26 did not differ among treatments. Conception rates of all second services, regardless of when they occurred after CIDR removal, estrogen injection, or both, also were not different among treatments (Table 8). Limited numbers of cows per treatment likely precluded detection of any significant effects. 


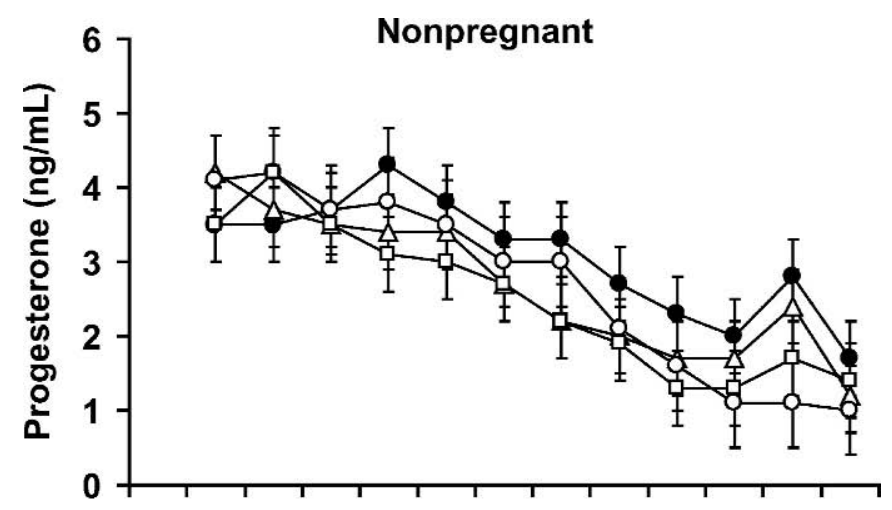

$\begin{array}{llllllllllll}13 & 14 & 15 & 16 & 17 & 18 & 19 & 20 & 21 & 22 & 23 & 24\end{array}$

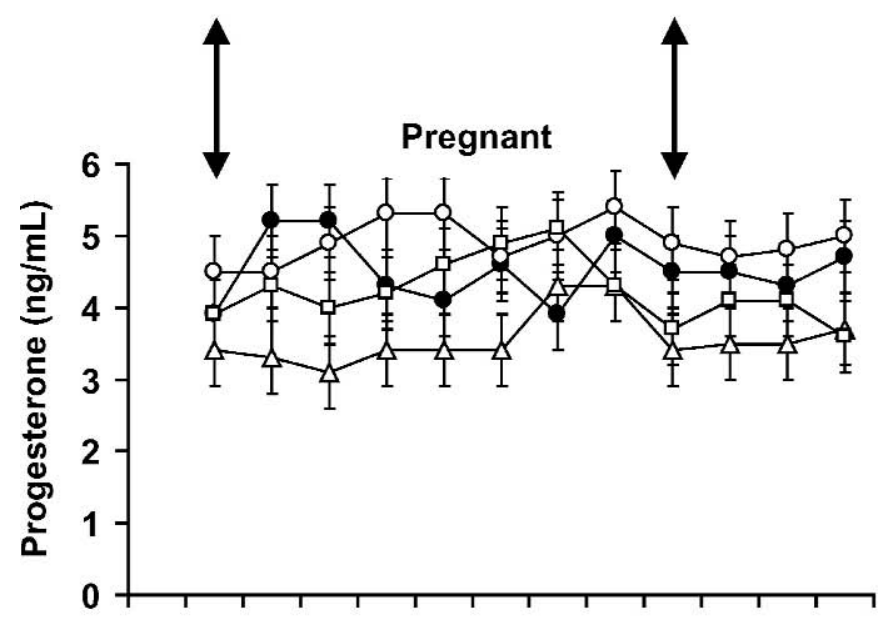

$\begin{array}{llllllllllll}13 & 14 & 15 & 16 & 17 & 18 & 19 & 20 & 21 & 22 & 23 & 24\end{array}$

\section{Days after TAI}

Figure 6. Concentrations of progesterone in the blood serum of nonpregnant and pregnant cows on d 13 to 24 after timed AI (TAI) in experiment 2 . Cows were previously treated with a once-used controlled internal drug-releasing intravaginal insert containing progesterone (CIDR) between d 13 and 20 (control; closed circles) after TAI or with the CIDR plus injections of $1 \mathrm{mg}$ of estradiol benzoate (EB; open triangles) or 0.5 (open circles) or 1.0 (open squares) $\mathrm{mg}$ of estradiol cypionate (ECP) on d 13 and 21. Number of nonpregnant cows illustrated ranged from 12 to 15 per treatment. Number of pregnant cows illustrated ranged from 11 to 16 per treatment. Arrows indicate estrogen injections.

\section{DISCUSSION}

One purpose of these studies was to increase return rates of cows to their first eligible estrus after TAI. Reuse of CIDR after previous insemination did synchronize returns to estrus in nonpregnant and a few pregnant cows in both experiments. Our treatments, however, failed to increase the proportion of eligible nonpregnant cows returning to estrus. Our findings are consistent with earlier studies in which the estrus for those that were detected was synchronized via reuse of CIDR per vagina for 5 to $7 \mathrm{~d}$ in beef cattle (McMillan and Macmillan, 1989; Stevenson et al., 2003), dairy heifers (Van Cleeff et al., 1996), or lactating dairy cattle (Chenault et al., 2003a; McDougall and Loeffler, 2004). In experiment 1,8 cows subsequently diagnosed pregnant $8 \mathrm{~d}$ after CIDR removal ( 8 of $134 ; 6 \%$ ) and 8 pregnant controls ( 8 of $128 ; 6.3 \%$ ) were detected in estrus and were reinseminated between d 20 and 26 after TAI. Their return pattern also was synchronous with that of nonpregnant cows (Figure 3). Occurrence of estrus in pregnant cows was not observed in experiment 2 , because none were detected in estrus between 0 and $26 \mathrm{~d}$ after TAI in any of the 4 treatments. Cows in experiment 2 were not chalked and locked daily for reading of chalk marks as were all cows used at 2 commercial dairies in experiment 1. Expression of spontaneous estrus in pregnant cows as observed in experiment 1 is rare, but not inconsistent with an earlier report in which 5.6\% of 6751 pregnant cows reportedly expressed estrus even though their pregnancies terminated in nonabortive calvings (Erb and Morrison, 1957).

Treatment with a previously used CIDR insert as a source of $\mathrm{P} 4$ for $7 \mathrm{~d}$ after TAI in experiment $1 \mathrm{did}$ not improve rates of return of estrus. In contrast, compared with non-CIDR-treated controls, increased return rates were reported for lactating dairy cows treated with a new CIDR for $7 \mathrm{~d}$ beginning 13 to $15 \mathrm{~d}$ after a previous AI in other studies (Chenault et al., 2003a; McDougall and Loeffler, 2004). In the latter study, $0.5 \mathrm{mg}$ of EB was administered at CIDR insert and again $24 \mathrm{~h}$ after CIDR removal. In the former study and in experiment 1 , cows that returned to estrus did so more synchronously than controls. Addition of estrogen injections in experiment 2 did not further increase overall return rates to the first eligible estrus (second service), although the rates of return were numerically greater than for those returning 20 to $26 \mathrm{~d}$ after TAI in the P4-treated controls in experiment $2(58.6 \%$ vs. $44.6 \%$; Table 8$)$ compared with experiment 1 (30.8\% vs. 27\%; Table 2). This difference likely occurred because the electronic estrus-detection devices were used in experiment 2.

One mechanism whereby $\mathrm{P} 4$ initially released from the CIDR inserts may produce a synchronous estrus after insert removal (Figure 4) is the ability of the initial P4 increase to cause follicle turnover, as was demonstrated when new CIDR were applied to late luteal phase heifers (Kang et al., 1999). Although concentrations of serum P4 were greater in previously inseminated and subsequently CIDR-treated suckled beef cows than in controls after $7 \mathrm{~d}$ of treatment (Stevenson et al., 2003), we could not detect a significant difference in blood concentrations of $\mathrm{P} 4$ on d 20 in lactating dairy cows at insert removal between controls and CIDRtreated cows that returned to estrus between 20 and 26 $\mathrm{d}$ after TAI in experiment 1 (Figure 4). Lack of observed 
Table 4. Concentrations of progesterone (ng/mL) in the blood serum of cows at $0,24,48$, and $72 \mathrm{~h}$ after injections with estrogen on d 13 and 21 after timed AI (TAI; Experiment 2).

\begin{tabular}{|c|c|c|c|c|c|c|c|c|c|c|c|c|}
\hline \multirow[b]{3}{*}{ Treatment $^{1}$} & \multicolumn{6}{|c|}{ Nonpregnant } & \multicolumn{6}{|c|}{ Pregnant } \\
\hline & \multirow[b]{2}{*}{ no. } & \multicolumn{4}{|c|}{ Hours after treatment } & \multirow[b]{2}{*}{$\pm \mathrm{SE}$} & \multirow[b]{2}{*}{ no. } & \multicolumn{4}{|c|}{ Hours after treatment } & \multirow[b]{2}{*}{$\pm \mathrm{SE}$} \\
\hline & & 0 & 24 & 48 & 72 & & & 0 & 24 & 48 & 72 & \\
\hline & & & & & & d $13 a$ & $\mathrm{er} \mathrm{T}$ & & & & & \\
\hline Control & 13 & 3.8 & 3.7 & 4.0 & 4.5 & 0.4 & 16 & 3.8 & 5.1 & 5.1 & 4.2 & 0.5 \\
\hline $\mathrm{EB}-1.0$ & 12 & 3.8 & 3.5 & $3.2 \dagger$ & $3.2^{*}$ & 0.4 & 16 & 3.6 & $3.5^{* *}$ & $3.3^{* *}$ & 3.5 & 0.5 \\
\hline $\mathrm{ECP}-0.5$ & 12 & $4.5 \dagger$ & $4.7^{*}$ & 4.0 & 4.2 & 0.4 & 11 & 4.2 & 4.3 & 4.7 & 5.1 & 0.5 \\
\hline $\mathrm{ECP}-1.0$ & 15 & 3.9 & $4.6 \dagger$ & 3.8 & $3.4^{*}$ & 0.4 & 12 & 4.0 & 4.4 & $4.1 \dagger$ & 4.3 & 0.5 \\
\hline Contr & 29 & 18 & 1.5 & 1.6 & 10 & 0.4 & 22 & 4.4 & 42 & 4. & 4.6 & 0.5 \\
\hline $\mathrm{EB}-1.0$ & 26 & $1.0^{*}$ & 0.9 & 1.3 & 0.7 & 0.4 & 22 & $3.2^{*}$ & $3.3 \dagger$ & 3.4 & $3.7 \dagger$ & 0.5 \\
\hline $\mathrm{ECP}-0.5$ & 27 & 1.3 & 0.9 & $0.8 \dagger$ & 0.7 & 0.4 & 15 & 4.2 & 4.1 & 4.5 & 4.7 & 0.6 \\
\hline $\mathrm{ECP}-1.0$ & 29 & $0.7^{* *}$ & $0.7 \dagger$ & $0.8 \dagger$ & 0.8 & 0.4 & 17 & 3.8 & 3.8 & 4.2 & $3.4 \dagger$ & 0.6 \\
\hline
\end{tabular}

\footnotetext{
${ }^{1}$ All cows were treated with a once-used controlled internal drug releasing intravaginal insert containing (CIDR) for $7 \mathrm{~d}$ between d 13 and 20 after a TAI. Controls received no further treatment, whereas the remaining cows were injected with either $1 \mathrm{mg}$ of estradiol benzoate (EB - 1.0), $0.5 \mathrm{mg}$ of estradiol cypionate (ECP - 0.5), or $1.0 \mathrm{mg}$ of estradiol cypionate (ECP - 1.0) on d 13 and 21 ( $24 \mathrm{~h}$ after CIDR removal).

$\dagger$ Tended $(P<0.10)$ to differ from control within pregnancy status and hour after treatment on $\mathrm{d} 13$ or

*Different $(P<0.05)$ from control within pregnancy status and hour after treatment on d 13 or 21.
} 21

differences in serum $\mathrm{P} 4$ could be due to multiple factors, including variability in $\mathrm{P} 4$ concentrations in control cows on d 20, low residual P4 in used CIDR, and the fact that new CIDR only increase P4 marginally compared with changes during the luteal phase or during pregnancy (Chenault et al., 2003b). In addition, because of significantly greater DMI and milk yields of dairy (Sangsritavong et al., 2002) vs. beef cows, perhaps the greater metabolic clearance of progesterone partly explains the lack of differences in progesterone in serum after treatment with a CIDR.

The purpose of the first estrogen injection in experiment 2 was to initiate a new follicular wave so that emergence of a new follicle was induced during $\mathrm{P} 4$ treat- ment. A small dose of EB injected on d 12, 13, or 14 after AI synchronized returns to service to a 9- to 10$\mathrm{d}$ period and increased fertility associated with the second AI, whereas pregnancy rates to the initial AI remained unchanged (Macmillan et al., 1997). For those cows in our study that responded with follicle turnover, interval to new wave emergence was 4 to $5 \mathrm{~d}$ (Table 5), consistent with findings in nonlactating cattle after treatment with $1 \mathrm{mg}$ of EB during mid diestrus (Bo et al., 1995; Macmillan et al., 1999; Burke et al., 2000). Injections or intravaginal treatments of cattle with $\mathrm{EB}$ attenuated growth of the second dominant follicle of the estrous cycle in both second and third wave cows and caused emergence of a new wave of follicular

Table 5. Emergence of the second dominant follicle in second and third wave cows and the third dominant follicle in third wave cows (Experiment 2).

\begin{tabular}{|c|c|c|c|c|c|}
\hline \multirow[b]{2}{*}{ Treatment $^{1}$} & \multicolumn{2}{|c|}{$\begin{array}{l}\text { Day of emergence of } \\
\text { second dominant follicle }\end{array}$} & \multirow{2}{*}{\multicolumn{2}{|c|}{$\begin{array}{l}\text { Day of emergence of } \\
\text { third dominant follicle }\end{array}$}} & \multirow{2}{*}{$\begin{array}{l}\text { Proportion } \\
\text { of cows with } \\
3 \text { waves }\end{array}$} \\
\hline & Second wave & Third wave & & & \\
\hline & $\longrightarrow($ & after timed $\mathrm{AI}$ & {[} & (d after treatment) & $(\%)$ \\
\hline CIDR & $14.6 \pm 0.6(13)^{2}$ & $11.9 \pm 1$ & $20.0 \pm 1.0(3)^{*}$ & $7.0 \pm 1.0(3)^{*}$ & 18.8 \\
\hline $\mathrm{CIDR}+\mathrm{EB}-1.0$ & $15.6 \pm 0.7(12)$ & $13.0 \pm 1.0$ & $17.1 \pm 0.7(4)$ & $4.1 \pm 0.7$ & 25 \\
\hline CIDR + ECP -0.5 & $14.3 \pm 0.9(8)$ & $12.0 \pm 1.0(5)$ & $17.1 \pm 0.8$ & $4.1 \pm 0.8(5)$ & 38.5 \\
\hline CIDR + ECP -1.0 & $16.1 \pm 0.9(7)$ & $13.0 \pm 0.8(7)$ & $18.0 \pm 0.5(7)$ & $5.0 \pm 0.5(7)$ & 50 \\
\hline
\end{tabular}

${ }^{1}$ All cows were treated with a once-used controlled internal drug-releasing intravaginal insert (CIDR) for $7 \mathrm{~d}$ between $\mathrm{d} 13$ and 20 after a timed AI. Controls received no further treatment, whereas the remaining cows were injected with either $1 \mathrm{mg}$ of estradiol benzoate (EB - 1.0), $0.5 \mathrm{mg}$ of estradiol cypionate (ECP $0.5)$, or $1.0 \mathrm{mg}$ of estradiol cypionate (ECP - 1.0) on d 13 and 21 (24 h after CIDR removal). Ovaries were scanned by transrectal ultrasonography between d 13 and 24 after timed AI.

${ }^{2}$ Number of cows.

*Different $(P<0.05)$ from all estrogen doses. 
Table 6. Percentage returns to estrus after timed AI (TAI) as determined by electronic detection of estrus (experiment 2).

\begin{tabular}{|c|c|c|c|c|c|c|}
\hline \multirow[b]{2}{*}{ Item } & \multicolumn{6}{|c|}{ Treatment $^{1}$} \\
\hline & $\begin{array}{l}\text { CIDR } \\
\text { control }\end{array}$ & $\begin{array}{l}\text { CIDR + } \\
\text { estrogen }\end{array}$ & $\begin{array}{l}\mathrm{CIDR}+ \\
\mathrm{EB}-1.0\end{array}$ & $\begin{array}{l}\mathrm{CIDR}+ \\
\mathrm{ECP}-0.5\end{array}$ & $\begin{array}{l}\mathrm{CIDR}+ \\
\mathrm{ECP}-1.0\end{array}$ & Total \\
\hline & & $-(\%$ & o.] returnec & f nonpregn & t cows) & \\
\hline \multirow{5}{*}{$\begin{array}{l}\text { Less than } 20 \mathrm{~d} \text { after TAI } \\
\mathrm{d} 20 \text { to } 26 \text { after TAI } \\
\text { More than } 26 \mathrm{~d} \text { after TAI } \\
\text { No return after TAI }\end{array}$} & $0.0(0)$ & $2.2(2)$ & $0.0(0)$ & $5.6(2)$ & $0.0(0)$ & $1.6(2)$ \\
\hline & $48.4(15)$ & $60.2(56)$ & $74.1(20)$ & $58.3(21)$ & $50.0(15)$ & $57.3^{* *}(71)$ \\
\hline & $51.6(16)$ & $36.6(34)$ & $25.9(7)$ & $36.1(13)$ & $46.7(14)$ & $40.3 \dagger(49)$ \\
\hline & $0.0(0)$ & $1.1(1)$ & $0.0(0)$ & $0.0(0)$ & $3.3(1)$ & $0.8 * *(1)$ \\
\hline & \multicolumn{6}{|c|}{ (\% [no.] returned of pregnant cows) } \\
\hline Less than $20 \mathrm{~d}$ after TAI & $0.0(0)$ & $0.0(0)$ & $0.0(0)$ & $0.0(0)$ & $0.0(0)$ & $0.0(0)$ \\
\hline d 20 to 26 after TAI & $0.0(0)$ & $0.0(0)$ & $0.0(0)$ & $0.0(0)$ & $0.0(0)$ & $0.0(0)$ \\
\hline More than $26 \mathrm{~d}$ after TAI & $21.1(4)$ & $30.2(16)$ & $25.0(5)$ & $33.3(5)$ & $33.3(6)$ & $27.8(20)$ \\
\hline No return after TAI & $78.9(15)$ & $69.8(37)$ & 75.0 & $66.7(10)$ & $66.7(12)$ & $72.2(55)$ \\
\hline
\end{tabular}

${ }^{1}$ All cows were treated with a once-used controlled internal drug releasing intravaginal insert containing (CIDR) for $7 \mathrm{~d}$ between $\mathrm{d} 13$ and 20 after a TAI. Controls received no further treatment, whereas the remaining cows were injected with either $1 \mathrm{mg}$ of estradiol benzoate (EB - 1.0), $0.5 \mathrm{mg}$ of estradiol cypionate (ECP - 0.5), or $1.0 \mathrm{mg}$ of estradiol cypionate (ECP - 1.0) on d 13 and 21 ( $24 \mathrm{~h}$ after CIDR removal).

${ }^{2}$ Includes all cows treated with a CIDR plus estrogen injections.

$\dagger$ Tended $(P=0.07)$ to differ from pregnant cows within return category.

**Different $(P<0.01)$ from pregnant cows within return category.

growth 4 to $5 \mathrm{~d}$ after EB treatment (Burke et al., 1999, 2000).

The purpose of the second estrogen injection was to induce estrus and an LH surge and subsequently reduce the time necessary to detect the resynchronized first eligible estrus after previous AI. Second injections of EB reduced the time to the next eligible estrus so that more cows returned to estrus sooner (Macmillan et al., 1997). It has been demonstrated that $1 \mathrm{mg}$ of $\mathrm{EB}$ is sufficient to elicit behavioral signs of estrus in anestrous beef cows (Fike et al., 1997). Administration of 0.5 or $1 \mathrm{mg}$ of ECP induced an LH surge in lactating dairy cows (Stevenson et al., 2004) and heifers (Lopes et al., 2000) after $\mathrm{PGF}_{2 \alpha}$-induced luteolysis. Adminis- tration of EB at CIDR removal on d 20 of cycle has been used to reduce variability in the timing of $\mathrm{LH}$ surge (Hanlon et al., 1996).

In experiment 2, EB or either dose of ECP $24 \mathrm{~h}$ after CIDR removal reduced intervals to estrus compared with cows treated with $\mathrm{P} 4$ alone. Mean interval to estrus was decreased by EB treatment when given during the follicular phase of the estrous cycle (Ryan et al., 1995). In experiment 2 , intervals to estrus (Table 7) and concentrations of E2-17 $\beta$ (Figure 5) are consistent with the half-lives of these 2 forms of estrogen and their rates of absorption and enzymatic conversion to E2$17 \beta$. Serum concentrations of E2-17 $\beta$ reached supraphysiologic concentrations 1 to $23 \mathrm{~h}$ after treatment

Table 7. Characteristics of return to estrus after estrogen treatments on d 21 after timed AI (TAI) as determined by electronic detection of estrus (experiment 2 ).

\begin{tabular}{lllll}
\hline & \multicolumn{4}{c}{ Treatment $^{1}$} \\
\cline { 2 - 5 } Item & CIDR & CIDR + & CIDR + & CIDR + \\
& control & EB -1.0 & ECP - 0.5 & ECP - 1.0 \\
\hline Cows, no. & 12 & 17 & 19 & 13 \\
Interval to estrus, h & $47 \pm 7^{* *}$ & $23 \pm 6$ & $33 \pm 5$ & $24 \pm 7$ \\
Duration of estrus, $h$ & $6.7 \pm 1.8$ & $7.3 \pm 1.5$ & $8.0 \pm 1.3$ & $5.2 \pm 1.7$ \\
Frequency of standing events, no. & $8 \pm 4$ & $14 \pm 4$ & $12 \pm 3$ & $12 \pm 4$ \\
Duration of total standing events, $\mathrm{s}$ & $17 \pm 8$ & $34 \pm 7$ & $22 \pm 6$ & $22 \pm 8$ \\
Duration of individual events, $\mathrm{s}$ & $2.1 \pm 0.3$ & $2.6 \pm 0.2^{*}$ & $1.9 \pm 0.2$ & $1.9 \pm 0.3$ \\
\hline
\end{tabular}

\footnotetext{
${ }^{1}$ All cows were treated with a once-used controlled internal drug releasing intravaginal insert containing (CIDR) for $7 \mathrm{~d}$ between $\mathrm{d} 13$ and 20 after a TAI. Controls received no further treatment, whereas the remaining cows were injected with either $1 \mathrm{mg}$ of estradiol benzoate (EB - 1.0), $0.5 \mathrm{mg}$ of estradiol cypionate (ECP - 0.5), or $1.0 \mathrm{mg}$ of estradiol cypionate (ECP - 1.0) on d 13 and 21 (24 h after CIDR removal).

*Different $(P<0.05)$ from estrogen treatments.

**Different $(P<0.01)$ from estrogen treatments.
} 
Table 8. Fertility of established pregnancies after timed AI (TAI) and resulting embryo survival, and resynchronized conception rates after treatments with progesterone (P4)-releasing intravaginal inserts (CIDR) and (or) estrogen injections (experiment 2).

\begin{tabular}{|c|c|c|c|c|c|}
\hline \multirow[b]{2}{*}{ Item } & \multicolumn{5}{|c|}{ Treatment $^{1}$} \\
\hline & $\begin{array}{l}\text { CIDR } \\
\text { control }\end{array}$ & $\begin{array}{l}\text { CIDR + } \\
\text { estrogen }\end{array}$ & $\begin{array}{l}\mathrm{CIDR}+ \\
\mathrm{EB}-1.0\end{array}$ & $\begin{array}{l}\mathrm{CIDR}+ \\
\mathrm{ECP}-0.5\end{array}$ & $\begin{array}{l}\mathrm{CIDR}+ \\
\mathrm{ECP}-1.0\end{array}$ \\
\hline & & & $(\%[$ no. $])$ & & \\
\hline \multicolumn{6}{|l|}{ Pregnancy rates resulting from $\mathrm{TAI}^{3}$} \\
\hline Elevated serum $\mathrm{P}^{4}$ on $\mathrm{d} 20$ through 24 & $42.2(50)$ & $38.6(146)$ & $45.0(47)$ & $28.1(51)$ & $42.0(48)$ \\
\hline Ultrasonography on d 28 & $37.8(50)$ & $36.2(146)$ & $42.4(47)$ & $27.5(51)$ & $37.9(48)$ \\
\hline Palpation on $\mathrm{d} 40$ to 46 & $30.7(50)$ & $29.7(146)$ & $32.7(47)$ & $22.6(51)$ & $32.7(48)$ \\
\hline Ultrasonography on d 56 & $31.0(50)$ & $28.7(146)$ & $33.1(47)$ & $21.0(51)$ & $31.0(48)$ \\
\hline \multicolumn{6}{|l|}{ Embryo survival of timed $\mathrm{AI}^{5}$} \\
\hline d 24 to 28 & $75.3(25)$ & $88.1 \dagger(61)$ & $96.1(21)$ & $85.5(19)$ & $87.1(21)$ \\
\hline d 28 to 40 to 46 & $81.1(19)$ & $83.1(53)$ & $77.2(20)$ & $85.5(15)$ & $84.8(18)$ \\
\hline d 40 to 46 to 56 & 100 & $93.6(42)$ & 100 & $91.6(12)$ & $93.3(15)$ \\
\hline d 24 to 56 & $61.2(25)$ & $71.4(61)$ & $73.8(21)$ & $69.0(19)$ & $73.0(21)$ \\
\hline Return rates to second services ${ }^{6}$ & $44.6(31)$ & $58.6(92)$ & $70.5(27)$ & $60.1(36)$ & $47.3(29)$ \\
\hline Resynchronized conception rates ${ }^{6}$ & $25.9(14)$ & $26.3(55)$ & $19.8(20)$ & $35.7(21)$ & $20.6(13)$ \\
\hline Conception rates of all second services & $33.1(33)$ & $27.8(100)$ & $23.0(33)$ & $32.2(37)$ & $27.2(30)$ \\
\hline
\end{tabular}

\footnotetext{
${ }^{1}$ All cows were treated with a once-used controlled internal drug releasing intravaginal insert containing (CIDR) for $7 \mathrm{~d}$ between $\mathrm{d} 13$ and 20 after a TAI. Controls received no further treatment, whereas the remaining cows were injected with either $1 \mathrm{mg}$ of estradiol benzoate (EB - 1.0), $0.5 \mathrm{mg}$ of estradiol cypionate (ECP - 0.5), or $1.0 \mathrm{mg}$ of estradiol cypionate (ECP - 1.0) on d 13 and 21 (24 h after CIDR removal). Values are least squares percentages.

${ }^{2}$ Includes all cows treated with a CIDR insert plus estrogen injections.

${ }^{3}$ Pregnancy rates resulting from the initial insemination (TAI). Days are relative to initial TAI. Concentrations of progesterone for pregnant cows were $\geq 1 \mathrm{ng} / \mathrm{mL}$ on d 20 to 24 , inclusively.

${ }^{4} \mathrm{P} 4$ = progesterone.

${ }^{5}$ Embryonic survival relative to pregnancies established after initial TAI.

${ }^{6}$ Percentage of cows that returned to estrus between 20 and $26 \mathrm{~d}$ after TAI ( 0 and $6 \mathrm{~d}$ after CIDR removal) and their resulting conception rates. All of these are cows were diagnosed not pregnant $29 \mathrm{~d}$ after TAI.

$\dagger$ Tended $(P=0.10)$ to differ from control.
}

with $10 \mathrm{mg}$ of EB and remained elevated for 20 to 30 h (Vynckier et al., 1990). Further, a marked increase in $\mathrm{E} 2-17 \beta$ did not occur after administration of $10 \mathrm{mg}$ of ECP as it did it for administration of EB, and the maximum concentration of E2-17 $\beta$ was observed after 13 to $31 \mathrm{~h}$ and remained elevated for $170 \mathrm{~h}$ (Vynckier et al., 1990). Our observations for concentrations of E2$17 \beta$ after smaller doses of EB or ECP are consistent with that report.

Consistent with results in experiment 2 (Table 7), others have demonstrated that administration of $\mathrm{EB}$ alters interval to or distribution of estrus, with more estrogen-treated heifers and cows exhibiting estrus. More estrogen-treated heifers were detected in estrus $72 \mathrm{~h}$ after $\mathrm{P} 4$ withdrawal than in controls (Lane et al., 2001). Further, submission rates were increased in dairy cows after EB injection $48 \mathrm{~h}$ after $\mathrm{P} 4$ withdrawal (Macmillan et al., 1999). In another report, however, EB did not alter interval to estrus (Hanlon et al., 1997). Further, treatment with EB $48 \mathrm{~h}$ after induced luteolysis did not increase significantly the proportion of cows in estrus compared with those not receiving EB (Welch et al., 1975). All cows in experiment 2, including controls, received a previously used CIDR on d 13 after
TAI for $7 \mathrm{~d}$, which explains some synchrony occurring in the controls, as observed in experiment 1.

Synchronized conception rates at the first eligible estrus after CIDR removal did not differ, but tended to be less in experiment 1 , particularly in the herd with the better fertility at the synchronized estrus. In a recent large scale study (Chenault et al., 2003a), P4 administered via new CIDR had no negative effects on resynchronized conception rates, but did reduce slightly pregnancy rates of treated cows that were already pregnant. Less P4 concentrations in the absence of a functional CL are known to cause dominant follicles to persist and fail to turn over normally, resulting in oocytes of impaired fertility (Mihm et al., 1994; Ahmad et al., 1995). It is possible that some cows with early luteolysis during P4 treatment formed persistent follicles, resulting in reduced conception upon removal of CIDR.

In experiment 2, when P4 (used CIDR) plus estrogen injections were tested, synchronized conception rates did not differ. In our experiment, estrogen treatments reduced serum $\mathrm{P} 4$ concentrations in both nonpregnant and pregnant cows relative to controls. These results are consistent with those reported by Burke et al. (1999), in which plasma P4 concentrations declined by 
$2 \mathrm{ng} / \mathrm{mL}$ by $2 \mathrm{~d}$ after EB injection. Also consistent with our results (Table 4), it was reported that at least $2 \mathrm{~d}$ were required for estradiol to suppress endogenous P4 concentration (Munro and Moore, 1985). On d 21, P4 concentrations were already less in the EB - 1.0-treated cows than in controls and remained so for at least 24 h. Concentrations of P4 in estrogen-treated cows declined in a similar rate to the controls, which is consistent with those results reported by Burke et al. (1999).

Effects of EB on reduced luteal function and size of the CL might be best described as antiluteotrophic (Lemon, 1975). In some reports, diameter of the CL tended to decrease at faster rates in cows treated with the combination of P4 and EB than in controls (Burke et al., 1999). Therefore, estrogen treatment might have impaired luteal function in all cows through decreasing the natural luteotropin (LH) and subsequent endogenous $\mathrm{P} 4$ secretion.

Injections of ECP and EB were relatively unsuccessful at initiating new follicular waves in lactating dairy cows when inserted $13 \mathrm{~d}$ after TAI (approximately d 13 of the estrous cycle or of pregnancy). Although the interval from estrogen treatment to follicle emergence in cows that responded is consistent with other reports (Bo et al., 1995; Burke et al., 1999, 2000), those studies were conducted in beef heifers and nonlactating cows. Studies conducted in lactating dairy cows given 0.5 or $1 \mathrm{mg}$ of ECP plus $100 \mathrm{mg}$ of P4 $3 \mathrm{~d}$ after ovulation showed suppressed growth of the first dominant follicle of the estrous cycle and synchronous emergence of the second follicular wave, but when treatments were given at random stages of the cycle, wave emergence was asynchronous (Thundathil et al., 1997).

One report (Macmillan et al., 1999) indicated that CIDR + EB treatments increased conception rates at second service as a consequence of promoting 3 follicular waves. This was evident when conception rates were less in cows in which fertilized oocytes were derived from the second (58\%) compared with the third (95\%) follicular waves of the estrous cycle in beef (Ahmad et al., 1997) and dairy cows (30\% vs. 68\%; Townson et al., 2002). At the doses of EB or ECP used in experiment 2 , we failed to increase the proportion of cows with 3 follicular waves when treated with $\mathrm{P} 4$ via the CIDR insert plus estrogen injections on $\mathrm{d} 13$ and 21. Proportion of cows with 3 follicular waves was actually less in our P4-treated control cows (18.8\%) than was reported for untreated cycling lactating dairy cows (30\%; Townson et al., 2002). Perhaps larger doses of estrogen are necessary to cause follicle turnover in lactating dairy cows because of their inherent higher clearance of steroids in comparison with nonlactating cattle (Sangsritavong et al., 2002).
A key component of hormonal interventions used to resynchronize estrus is that treatments must have no detrimental effects on conceptions established at a previous insemination. In both experiments, neither the CIDR nor addition of estrogen injections had detrimental effects on established pregnancies. Moreover, established pregnancies of lactating dairy cattle were not harmed when injections of EB were administered on d 12, 13, or 14 after AI (Macmillan et al., 1997). In addition, injection of $1 \mathrm{mg}$ of $\mathrm{EB}$ or $0.5 \mathrm{mg} \mathrm{ECP}$ administered at insertion and at removal of a used CIDR did not compromise the ability of the CL to maintain an established pregnancy in lactating beef cows (Stevenson et al., 2003). In contrast, a $11 \%$ reduction in established pregnancy rates was reported in lactating dairy cows that were treated with a new CIDR insert alone to resynchronize estrus (Chenault et al., 2003a).

Administration of $\mathrm{P} 4$ via the $\mathrm{P} 4$-releasing intravaginal device for $7 \mathrm{~d}$ after AI, starting either on $\mathrm{d} 5$ or 10 after AI, increased pregnancy rates to first AI in dairy cows during both time periods, but only increased blood P4 when treatment was initiated early after AI on d 5 (Robinson et al., 1989). Although no embryo survival was evaluated in the latter study, in the present study, which involved postinsemination application of the P4 (CIDR) without a concurrent estrogen injection (experiment 1), embryo survival between d 29 and 57 was improved significantly. Together, these studies provide preliminary evidence that postinsemination supplemental $\mathrm{P} 4$ provided some benefit to either pregnancy recognition and/or embryo survival to the fetal stage. Preliminary results of our second experiment indicate that combining estrogen with the CIDR did not further improve pregnancy rates by d 24 to 28 (no enhancement of pregnancy recognition), but tended to improve survival of embryos to $d 28$. This extended survival indicates that formation of extra embryonic membranes and initial attachment might have occurred (King et al., 1980, 1982). Although this potential initial enhancement of embryo survival was not significantly maintained to d 56, the combined CIDR + estrogen-treated cows had a numerical advantage to the CIDR control (71.4\% vs. $61.2 \%)$. Further study is warranted as to the potential role of estrogen and progesterone because intrauterine infusion of estrogen plus $\mathrm{PGE}_{2}$ every 6 $\mathrm{h}$ between $\mathrm{d} 13$ and 21 extended the estrous cycle of nonpregnant heifers (Reynolds et al., 1983).

In conclusion, resynchrony of the first eligible estrus after TAI was accomplished as measured by synchronized pattern of returns to estrus of those cows that were detected between d 20 and 26 , but overall return rates of all treated cows in excess of non-P4 treated controls were not increased. Addition of estrogen in experiment 2 failed to improve return rates above $\mathrm{P} 4$ - 
treated controls. Further study of such postinsemination treatments to improve resynchrony of the first eligible estrus and overall return rates after a previous insemination is warranted. Addition of estrogen turned over few ovarian follicles that were dominant when estrogen was injected on d 13 after TAI. For cows with follicles that responded to estrogen, emergence of the next follicular wave occurred in 4 to $5 \mathrm{~d}$. None of the treatments in either experiment reduced pregnancy rates in cows previously impregnated at TAI. That embryo survival was improved between d 29 and 57 in experiment 1 and tended to be improved between $\mathrm{d} 24$ and 28 in response to the CIDR + estrogen treatment warrants further study.

\section{REFERENCES}

Ahmad, N., F. N. Schrick, R. L. Butcher, and E. K. Inskeep. 1995. Effect of persistent follicles on early embryonic losses in beef cows. Biol. Reprod. 52:1129-1135.

Ahmad, N., E. C. Townsend, R. A. Dailey, and E. K. Inskeep. 1997. Relationships of hormonal patterns and fertility occurrence of two or three waves of ovarian follicles, before and after breeding, in beef cows and heifers. Anim. Reprod. Sci. 49:13-28.

Bo, G. A., G. P. Adams, R. A. Pierson, and R. J. Mapletoft. 1995. Exogenous control of follicular wave emergence in cattle. Theriogenology 43:31-40.

Burke, C. R., M. P. Boland, and K. L. Macmillan. 1999. Ovarian responses to progesterone and oestradiol benzoate administered intravaginally during dioestrus in cattle. Anim. Reprod. Sci. 55:23-33.

Burke, J. M., M. L. Day, C. R. Bunt, and K. L. Macmillan. 2000. Use of small dose of estradiol benzoate during diestrus to synchronize development of the ovulatory follicle in cattle. J. Anim. Sci. 78:145-151.

Burke, J. M., R. L. De la Sota, C. A. Risco, C. R. Staples, E. J.-P. Schmitt, and W. W. Thatcher. 1996. Evaluation of time insemination using a gonadotropin-releasing hormone agonist in lactating dairy cows. J. Dairy Sci. 79:1385-1393.

Chenault, J. R., J. F. Boucher, K. J. Dame, J. A. Meyer, and S. L. WoodFollis. 2003a. Intravaginal progesterone insert to synchronize return to estrus of previously inseminated dairy cows. J. Dairy Sci. 86:2039-2049.

Chenault, J. R., R. E. Hornish, Y. C. Anderson, L. F. Krabill, J. F. Boucher, and M. J. Prough. 2003b. Concentrations of progesterone in milk of cows administered an intravaginal progesterone insert. J. Dairy Sci. 86:2050-2060.

Dailey, R. A., J. C. Price, K. R. Simmons, E. M. Meisterling, P. A. Quinn, and S. P. Washburn. 1986. Synchronization of estrus in dairy cows with prostaglandin F2 alpha and estradiol benzoate. J. Dairy Sci. 69:1110-1114.

El-Zarkouny, S. Z., J. A. Cartmill, B. A. Hensley, and J. S. Stevenson. 2004. Presynchronization of estrous cycles before Ovsynch and progesterone in dairy cows: Ovulation, pregnancy rates, and embryo survival. J. Dairy Sci. 87:1024-1037.

Erb, R. E., and R. A. Morrison. 1957. Estrus after conception in a herd of Holstein-Friesian cattle. J. Anim. Sci. 16:267-270.

Fike, K. E., M. L. Day, E. K. Inskeep, J. E. Kinder, P. E. Lewis, R. E. Short, and H. D. Hafs. 1997. Estrus and luteal function in suckled beef cows that were anestrous when treated with an intravaginal device containing progesterone with or without a subsequent injection of estradiol benzoate. J. Anim. Sci. 75:2009-2015.

Hanlon, D. W., N. B. Williamson, J. J. Wichtel, I. J. Steffert, A. L. Craigie, and D. U. Pfeiffer. 1996. The effects of estradiol benzoate administration on estrous response and synchronized pregnancy rate in dairy heifers after treatment with exogenous progesterone. Theriogenology 45:775-785.

Hanlon, D. W., N. B. Williamson, J. J. Wichtel, I. J. Steffert, A. L. Craigie, and D. U. Pfeiffer. 1997. Ovulatory responses and plasma luteinizing hormone concentrations in dairy heifers after treatment with exogenous progesterone and estradiol benzoate. Theriogenology 47:963-975.

Kang, H., T. Nakao, K. Nakada, and M. Moriyoshi. 1999. Effect of CIDR treatment at day 16 of the estrous cycled on follicular growth in dairy heifers with two or three follicular waves. J. Reprod. Fertil. 45:57-63.

King, G. J., B. A. Atkinson, and H. A. Robertson. 1980. Development of the bovine placentome from days 20 to 29 of gestation. J. Reprod. Fertil. 59:95-100.

King, G. J., B. A. Atkinson, and H. A. Robertson. 1982. Implantation and early placentation in domestic ungulates. J. Reprod. Fertil. Suppl. 31:17-30.

Lane, E. A., E. J. Austin, J. F. Roche, and M. A. Crowe. 2001. The effects of estradiol benzoate on synchrony of estrus and fertility in cattle after removal of a progesterone-releasing intravaginal device. Theriogenology 55:1807-1818.

Lemon, M. 1975. The effect of oestrogen alone or in association with progestagens on the formation and regression of the corpus luteum of the cyclic cows. Ann. Biol. Anim. Biochim. Biophys. 15:243-253.

Lopes, F. L., D. R. Arnold, J. Williams, S. M. Pancarci, M. J. Thatcher, M. Drost, and W. W. Thatcher. 2000. Use of estradiol cypionate for timed insemination. J. Anim. Sci. 78(Suppl. 1):216. (Abstr.)

Macmillan, K. L., V. K. Taufa, and A. M. Day. 1997. Manipulating ovaries' follicle wave patterns can partially synchronize returns to service and increases the pregnancy rate to second insemination. Proc. N. Z. Soc. Anim. Prod. 57:237.

Macmillan, K. L., V. K. Taufa, A. M. Day, and V. M. Eagles. 1999. Some effects of post-oestrous hormonal therapies on conception rates and resubmission rates in lactating dairy cows. Vol. 1. Pages 195-208 in Fertility in the High Producing Dairy Cow. Occasional Publ. No. 26. Br. Soc. Anim. Sci., Penicuik, Scotland.

McDougall, S., and S. H. Loeffler. 2004. Resynchrony of postpartum dairy cows previously treated for anestrous. Theriogenology 61:239-253.

McMillan, W. H., and K. L. Macmillan. 1989. CIDR-B for managed reproduction in beef cows and heifers. Proc. N. Z. Soc. Anim. Reprod. 49:85-89.

Mihm, M., A. Baguisi, M. P. Boland, and J. F. Roche. 1994. Association between the duration of dominance of the ovulatory follicle and pregnancy rate in beef heifers. J. Reprod. Fertil. 102:123-130.

Munro, R. K., and N. W. Moore. 1985. Effects of progesterone, oestradiol benzoate and cloprostenol on luteal function in the heifers. J. Reprod. Fertil. 73:353-359.

National Research Council. 1989. Nutrient Requirement of Dairy Cattle. 5th rev. ed. Natl. Acad. Sci. Washington, DC.

Perry, R. C., L. R. Corah, G. H. Kiracofe, J. S. Stevenson, and W. E. Beal. 1991. Endocrine changes and ultrasonography of ovaries in suckled beef cows during resumption of postpartum estrous cycles. J. Anim. Sci. 69:2548-2555.

Pursley, J. R., M. O. Mee, and M. C. Wiltbank. 1995. Synchronization of ovulation in dairy cows using $\mathrm{PGF}_{2 \alpha}$ and $\mathrm{GnRH}$. Theriogenology 44:915-923.

Reynolds, L. P., D. A. Robertson, and S. P. Ford. 1983. Effects of intrauterine infusion of oestradiol-17 beta and prostaglandin E2 on luteal function in non-pregnant heifers. J. Reprod. Fertil. 69:703-709.

Robinson, N. A., K. E. Leslie, and J. S. Walton. 1989. Effect of treatment with progesterone on pregnancy rate and plasma concentrations of progesterone in Holstein cows. J. Dairy Sci. 72:202-207.

Ryan, D. P., S. Snijders, H. Yaakub, and K. J. O'Farrell. 1995. An evaluation of estrus synchronization programs in reproductive management of dairy herds. J. Anim. Sci. 73:3687-3695.

Sangsritavong, S., D. K. Combs, R. Sartori, L. E. Armentano, and M. C. Wiltbank. 2002. High feed intake increases liver blood flow and metabolism of progesterone and estradiol- $17 \beta$ in dairy cattle. J. Dairy Sci. 85:2831-2842. 
Skaggs, C. L., B. V. Able, and J. S. Stevenson. 1986. Pulsatile or continuous infusion of luteinizing hormone-releasing hormone and hormonal concentrations in prepubertal beef heifers. J. Anim. Sci. 62:1034-1048.

Stevenson, J. S., S. K. Johnson, M. A. Medina-Britos, A. M. Richardson, and G. C. Lamb. 2003. Resynchronization of estrus in cattle of unknown pregnancy status using estrogen, progesterone, or both. J. Anim. Sci. 81:1682-1692.

Stevenson, J. S., and M. O. Mee. 1991. Pregnancy rates of Holstein cows after postinsemination treatment with a progesterone-releasing intravaginal device. J. Dairy Sci. 74:3849-3856.

Stevenson, J. S., S. M. Tiffany, and M. C. Lucy. 2004. Use of estradiol cypionate as a substitute for GnRH in protocols for synchronizing ovulation in dairy cattle. J. Dairy Sci. 87:3298-3305.

Stumpf, T. T., M. W. Wolfe, M. L. Day, J. A. Stoos, P. L. Wolfe, R. J. Kittok, and J. E. Kinder. 1991. Effect of 17-beta-estradiol on the preovulatory surge of LH in the bovine female. Theriogenology 36:201-207.

Thundathil, J., J. P. Kastelic, and R. J. Mapletoft. 1997. Effect of estradiol cypionate (ECP) on ovarian follicular development and ovulation in dairy cattle. Can. J. Vet. Res. 61:314-316.
Townson, D. H., P. C. W. Tsang, W. R. Butler, M. Frajblat, L. C. Griel, Jr., C. J. Johnson, R. A. Milvae, and J. L. Pate. 2002. Relationship of fertility to ovarian follicular waves before breeding in dairy cows. J. Anim. Sci. 80:1053-1058.

Van Cleeff, J., K. L. Macmillan, M. Drost, M. C. Lucy, and W. W. Thatcher. 1996. Effects of administering progesterone at selected intervals after insemination of synchronized heifers on pregnancy rates and resynchronization of returns to service. Theriogenology 46:1117-1130.

Vynckier, L., M. Debackere, A. De Kruif, and M. Coryn. 1990. Plasma estradiol- $17 \beta$ concentrations in the cow during induced estrus and after injection of estradiol-17 $\beta$ benzoate and estradiol-17 $\beta$ cypionatẽa preliminary study. J. Vet. Pharmacol. Therapy 13:36-42.

Welch, J. A., A. J. Hacket, C. J. Cunningham, J. O. Heishman, S. P. Ford, R. Nadaraja, W. Hansel, and E. K. Inskeep. 1975. Control of estrus in lactating beef cows with prostaglandin $\mathrm{F}_{2 \alpha}$ and estradiol benzoate. J. Anim. Sci. 41:1686-1692.

Xu, Z. Z., L. J. Burton, and K. L. Macmillan. 1997. Reproductive performance of lactating dairy cows following estrus synchronization regimens with $\mathrm{PGF}_{2 \alpha}$ and progesterone. Theriogenology $47: 687-701$ 